\title{
Reversible and irreversible impacts of greenhouse gas emissions in multi-century projections with the NCAR global coupled carbon cycle-climate model
}

\author{
Thomas L. Frölicher · Fortunat Joos
}

Received: 28 March 2009/Accepted: 11 December 2009/Published online: 12 January 2010

(C) Springer-Verlag 2010

\begin{abstract}
The legacy of historical and the long-term impacts of 21 st century greenhouse gas emissions on climate, ocean acidification, and carbon-climate feedbacks are investigated with a coupled carbon cycle-climate model. Emission commitment scenarios with zero emissions after year 2100 and 21 st century emissions of 1,800 , 900 , and 0 gigatons of carbon are run up to year 2500. The reversibility and irreversibility of impacts is quantified by comparing anthropogenically-forced regional changes with internal, unforced climate variability. We show that the influence of historical emissions and of non- $\mathrm{CO}_{2}$ agents is largely reversible on the regional scale. Forced changes in surface temperature and precipitation become smaller than internal variability for most land and ocean grid cells in the absence of future carbon emissions. In contrast, continued carbon emissions over the 21 st century cause irreversible climate change on centennial to millennial timescales in most regions and impacts related to ocean acidification and sea level rise continue to aggravate for centuries even if emissions are stopped in year 2100. Undersaturation of the Arctic surface ocean with respect to aragonite, a mineral form of calcium carbonate secreted by marine organisms, is imminent and remains widespread. The volume of supersaturated water providing habitat to calcifying organisms is reduced from preindustrial 40 to $25 \%$ in 2100 and to $10 \%$ in 2300 for the high emission case. We conclude that
\end{abstract}

T. L. Frölicher $(\bowtie) \cdot$ F. Joos

Climate and Environmental Physics, Physics Institute,

University of Bern, Sidlerstrasse 5, 3012 Bern, Switzerland

e-mail: froelicher@climate.unibe.ch

T. L. Frölicher · F. Joos

Oeschger Centre for Climate Change Research,

University of Bern, 3012 Bern, Switzerland emission trading schemes, related to the Kyoto Process, should not permit trading between emissions of relatively short-lived agents and $\mathrm{CO}_{2}$ given the irreversible impacts of anthropogenic carbon emissions.

\section{Introduction}

Anthropogenic emissions of $\mathrm{CO}_{2}$ and other radiative forcing agents force the atmospheric composition, Earth's climate, and the chemical state of the ocean towards conditions that have most likely not occurred over the past 20 million years (Blackford and Gilbert 2007) and at a rate that is unprecedented at least during the last 22,000 years (Joos and Spahni 2008). The averaged atmospheric $\mathrm{CO}_{2}$ concentration of $386 \mathrm{ppm}$ in year 2008 is far above the natural range (172-300 ppm) of the last 800,000 years (Lüthi et al. 2008). The range of plausible 21st century emission pathways (Van Vuuren et al. 2008; Strassmann et al. 2009) lead to continued global warming, oceanic heat absorption and sea-level rise. Continued carbon emission will affect climate over the next millennium and beyond (Plattner et al. 2008) and related climate impacts pose a significant risk to the human society.

The primary goal of this study is to quantify the reversibility and irreversibility of impacts by 21 st century greenhouse gas (GHG) emissions on the regional to continental scale by comparing the magnitude of anthropogenically-forced regional changes with internal, unforced climate variability. Multi-century changes in temperature, precipitation, sea level rise, marine and terrestrial carbon storage are investigated in the detailed spatio-temporal setting of the atmosphere-ocean general circulation model NCAR CSM1.4-carbon. The magnitude, evolution, and underlying mechanisms of marine and terrestrial carbon 
cycle-climate feedbacks are discussed. Ocean acidification and the decadal-to-century timescales of changes in the chemical state of the ocean are addressed. Our set of emission commitment scenario simulations allow us to tackle important gaps in knowledge with respect to the legacy of historical and the impacts of 21st century GHG emissions on regional climate and to discuss forced changes in the context of Earth system variability.

Besides global warming, anthropogenic carbon emissions lead to ocean acidification. The ocean has absorbed $\mathrm{CO}_{2}$ at a rate equal to about one-third of that emitted to the atmosphere since preindustrial (Sabine et al. 2004). Ocean uptake of the weak acid $\mathrm{CO}_{2}$ causes a reduction in $\mathrm{pH}$, thus, ocean acidification leads to an alteration in the calcium carbonate $\left(\mathrm{CaCO}_{3}\right)$ precipitation equilibrium (Feely et al. 2004). This process is less discussed than climate change but potentially with equally far-reaching consequences. Marine organisms show a wide range of responses to decreases in $\mathrm{pH}$ and in the saturation state of sea water with respect to biogenic $\mathrm{CaCO}_{3}$ (Doney et al. 2009; Fabry et al. 2008; Iglesias-Rodriguez et al. 2008). Some taxa are likely to show enhanced calcification in a high- $\mathrm{CO}_{2}$ world (Iglesias-Rodriguez et al. 2008), but many species appear to be negatively affected by ocean acidification. These different responses are expected to affect competition among species, ecosystem structure, and overall community production of organic material and $\mathrm{CaCO}_{3}$. On the other hand, the impact of plausible changes in $\mathrm{CaCO}_{3}$ production and export on atmospheric $\mathrm{CO}_{2}$ is estimated to be small (Gehlen et al. 2007; Heinze 2004).

Siegenthaler and Oeschger (1978) demonstrated already 30 years ago with their box-diffusion carbon cycle model the long lifetime of an atmospheric $\mathrm{CO}_{2}$ perturbation and pointed out that carbon emissions must be reduced "if the atmospheric radiation balance is not to be disturbed in a dangerous way". More recent studies using Earth System Model of Intermediate Complexity (EMIC) further illustrate the millennium-scale lifetime of an atmospheric $\mathrm{CO}_{2}$ perturbation and the associated changes in temperature, sea level, precipitation and ocean chemistry (Archer et al. 2009; Eby et al. 2009; Archer and Brovkin 2008; Matthews and Caldeira 2008; Plattner et al. 2008; Schmittner et al. 2008; Solomon et al. 2009; Montenegro et al. 2007; Lenton et al. 2006; Caldeira and Wickett 2005). For example, Solomon et al. (2009) investigated reversibility in global mean temperature and sea level, and regional precipitation by combining long-term zero-emission projections of an EMIC and results from models used for the IPCC Fourth Assessment Report (AR4). Mikolajewicz et al. (2007) further discussed the long-term effect of anthropogenic $\mathrm{CO}_{2}$ emissions on climate and the carbon cycle in projections with a complex Earth system model. However, these studies considered $\mathrm{CO}_{2}$ emissions only in the simulations and none attempted to assess the reversibility and irreversibility of anthropogenically perturbed changes in climate and ocean acidification on a regional scale and in the context of variability.

Important gaps in knowledge remain. A key to guide emission mitigation and adaption efforts is to quantify the reversibility of the impacts of historical and 21 st century GHG emissions. Arguably more relevant for individual countries than global mean change is by how much and for how long anthropogenic changes exceed natural variability in individual regions. However, there is as yet no explicit quantification available to which extent the impacts of historical and 21st century GHG emissions are reversible on a regional scale and a number of questions remain. When will the perturbations in temperature, precipitation, or sea level become indistinguishable from natural climate variability in different regions? What is the legacy of the historical GHG emissions with respect to regional climate change and ocean acidification? Do 21st century emissions irreversibly impact not only global climate indicators but also regional climate? These questions can typically not be answered by using costefficient EMICs that do not represent internal variability and atmospheric circulation modes such as El Niño/Southern Oscillation. Fortunately, increased computing power and the inclusion of carbon cycle representations in coupled atmosphere-ocean general circulation models provide now the opportunity to close this information gap.

In this study, we quantify the reversible and irreversible commitment of 21 st century anthropogenic emissions on human timescales and their impacts for selected climate and chemical indicators on the regional to global scale. Zero-emission commitment simulations are conducted with a comprehensive climate-carbon model. All relevant anthropogenic GHG emissions as well as sulfate aerosols are taken into account, unlike in earlier long-term studies. The redistribution of anthropogenic carbon in the Earth system, surface warming, steric sea level rise, precipitation changes and ocean acidification are investigated. In addition to providing a range of model metrics for the set of scenarios, we also discuss selected processes in detail. Special emphasis has been put on ocean acidification in the Arctic, where surface waters are expected to become corrosive for the aragonite shells of marine organisms within the next decade (Steinacher et al. 2009a). The long-term evolution of individual marine and terrestrial carbon cycle feedback mechanisms and the underlying regional carbon stock changes are quantified. The application of the fully coupled carbon model in illustrative multi-gas emission commitment scenarios allows us for the first time to discuss multi-century reversibility and irreversibility of anthropogenically perturbed regional changes in comparison with unforced, internal variability in a self-consistent, 3-dimensional, dynamical setting. 


\section{Methods}

\subsection{The NCAR CSM1.4-carbon Model}

Simulations are performed with the Climate System Model of the National Centre for Atmospheric Research (NCAR CSM1.4-carbon) (Doney et al. 2006; Fung et al. 2005; Frölicher et al. 2009; Steinacher et al. 2009a). It is a fully coupled, global climate-carbon cycle model. Biogeochemistry is simulated with a modified version of the terrestrial biogeochemistry model CASA (Randerson et al. 1997) and a prognostic version (Doney et al. 2006) of the OCMIP-2 ocean biogeochemistry model (Najjar et al. 2007). Prognostic variables include phosphate, dissolved inorganic carbon, alkalinity, oxygen and dissolved organic phosphorus. The marine iron cycle is parametrized and a constant rain-ratio of $\mathrm{CaCO}_{3}$ to organic carbon of 0.07 and constant Redfield ratios are used. The model does not include marine sediments, which only need to be considered on longer timescales (Archer et al. 1998).

The CSM1.4-carbon physical and biogeochemical climatological mean states are broadly consistent with global ocean observations (Frölicher et al. 2009; Steinacher et al. 2009a). However, the simulated changes in atmospheric $\mathrm{CO}_{2}$ and climate presented here represent low estimates. The equilibrium climate sensitivity of the CSM1.4-carbon $\left(2^{\circ} \mathrm{C}\right.$ for a nominal doubling of atmospheric $\left.\mathrm{CO}_{2}\right)$ is at the lower end of the estimated range of $2-4.5^{\circ} \mathrm{C}$ (Meehl et al. 2007). The overall carbon cycle-climate feedback that tends to promote higher atmospheric $\mathrm{CO}_{2}$ and additional warming in most models is small in CSM1.4-carbon (Friedlingstein et al. 2006). CSM1.4-carbon has a relatively strong terrestrial $\mathrm{CO}_{2}$ fertilization mechanism that causes a high terrestrial uptake under rising $\mathrm{CO}_{2}$. The rates of carbon transfer among the different vegetation and soil pools are climate dependent. The ecosystem distribution remains time-invariant in all simulations. Carbon emissions by land use are prescribed as an external source, thereby neglecting anthropogenic land use-climate- $\mathrm{CO}_{2}$ fertilization interactions that tend to reduce carbon storage on land (Strassmann et al. 2008).

\subsection{Experimental design}

CSM1.4-carbon is forced with prescribed anthropogenic emissions of carbon and sulfur, and prescribed concentrations of $\mathrm{CH}_{4}, \mathrm{~N}_{2} \mathrm{O}$, CFC-11, CFC-12, other halogenated species, and $\mathrm{SF}_{6}$ over the period 1820-2500. Reconstructed emissions over the historical period up to the year 2000 are extended by several emission scenarios into the future (Fig. 1a). In the case "Hist", emissions are set to zero after 2000. In the simulations "High" and "Low", emissions are prescribed following the high emission scenario SRES A2 and the low emission scenario SRES B1 over the 21st century and set to zero from 2100 to 2500 . Cumulative carbon emissions are $397 \mathrm{GtC}, 1304 \mathrm{GtC}$, and $2196 \mathrm{GtC}$ in the Hist, Low, and High case, respectively. In comparison, total conventional fossil fuel resources are of order 5,000 GtC. Non- $\mathrm{CO}_{2}$ GHG concentrations were calculated for each scenario using simplified expressions following Joos et al. (2001) and Forster et al. (2007) as further described in Frölicher et al. (2009). An additional "no-warming" simulation is run in the High case where all radiative agents are kept at preindustrial values in the model's radiation module while the carbon cycle responds to $\mathrm{CO}_{2}$ emissions. Differences in results between this simulation and the High case are attributed to climate change. We also quantify to what extent the temperature decrease after the cessation of emissions is due to the decrease of non- $\mathrm{CO}_{2}$ GHGs and sulfur aerosols. For this, a 100 -year $\mathrm{CO}_{2}$-only simulation is performed by branching from the Hist case at year 2000 and keeping non- $\mathrm{CO}_{2}$ GHG concentrations and sulfur emissions at year 2000 levels. The sensitivity of the radiation module to sulfur emissions is tested by setting the sulfur emissions constant after the year 2100 for 40 years. A control simulation is used to detrend possible model drift according to Frölicher et al. (2009).

Steric sea level rise is computed from changes in sea water density. It includes both thermo- and halosteric changes, but thermosteric changes dominate in general. $\mathrm{pH}$, carbonate ion concentration, and the saturation state are calculated offline from modeled quantities using the standard OCMIP carbonate chemistry routines. ${ }^{1}$ As the CSM1.4-carbon model does not include silicate $\left(\mathrm{Si}(\mathrm{OH})_{4}\right)$, a seasonal cycle of observation-based $\left[\mathrm{Si}(\mathrm{OH})_{4}\right]$ from the World Ocean Atlas 2001 (Conkright et al. 2002) is used in all calculations of $\mathrm{pH}$ and calcium carbonate saturation state. Details about the calculation of the carbonate chemistry and the uncertainties arising from this treatment of $\mathrm{Si}(\mathrm{OH})_{4}$ can be found in Steinacher et al. (2009a).

\section{Results}

3.1 Projected changes in radiative forcing, atmospheric $\mathrm{CO}_{2}$, global mean surface temperature and sea level

We first discuss global mean changes for the range of scenarios and highlight the difference in temperature evolution between $\mathrm{CO}_{2}$-only and multi-gas emission scenarios. $\mathrm{CO}_{2}$ is the dominant anthropogenic forcing in all three scenarios. In the High case it contributes $80 \%\left(5.9 \mathrm{~W} \mathrm{~m}^{-2}\right)$

\footnotetext{
${ }^{1}$ http://www.ipsl.jussieu.fr/OCMIP/phase3/simulations/NOCES/ HOWTO-NOCES-3.html.
} 
Fig. 1 (a) Prescribed cumulated fossil fuel and land use carbon emissions. Time series of simulated global annual mean, (b) atmospheric $\mathrm{CO}_{2}$, (c) atmospheric surface temperature change, $(\mathbf{d})$ steric sea level rise, $(\mathbf{e})$ ocean surface saturation with respect to aragonite and (f) ocean surface $\mathrm{pH}$. Inset panel in (c) shows the decrease in global mean surface temperature over the period 2000-2100 due to cessation of $\mathrm{CO}_{2}$ only in year 2000 (green line). The difference between the black and the green line denotes the impact of the non$\mathrm{CO}_{2}$ GHGs on the temperature decrease. (g) Evolution of the cumulative airborne fraction (red), terrestrial uptake fraction (green) and ocean uptake fraction (blue) of anthropogenic $\mathrm{CO}_{2}$. First 100 years of simulation are masked out. (h) Simulated global annual mean changes in the entire ocean volume of supersaturated (blue to red) and undersaturated (green) waters with respect to aragonite. The difference in simulated sea level in the nowarming case relative to the control is likely related to changes in the hydrological cycle in response to $\mathrm{CO}_{2}$ fertilization and increased water use efficiency on land
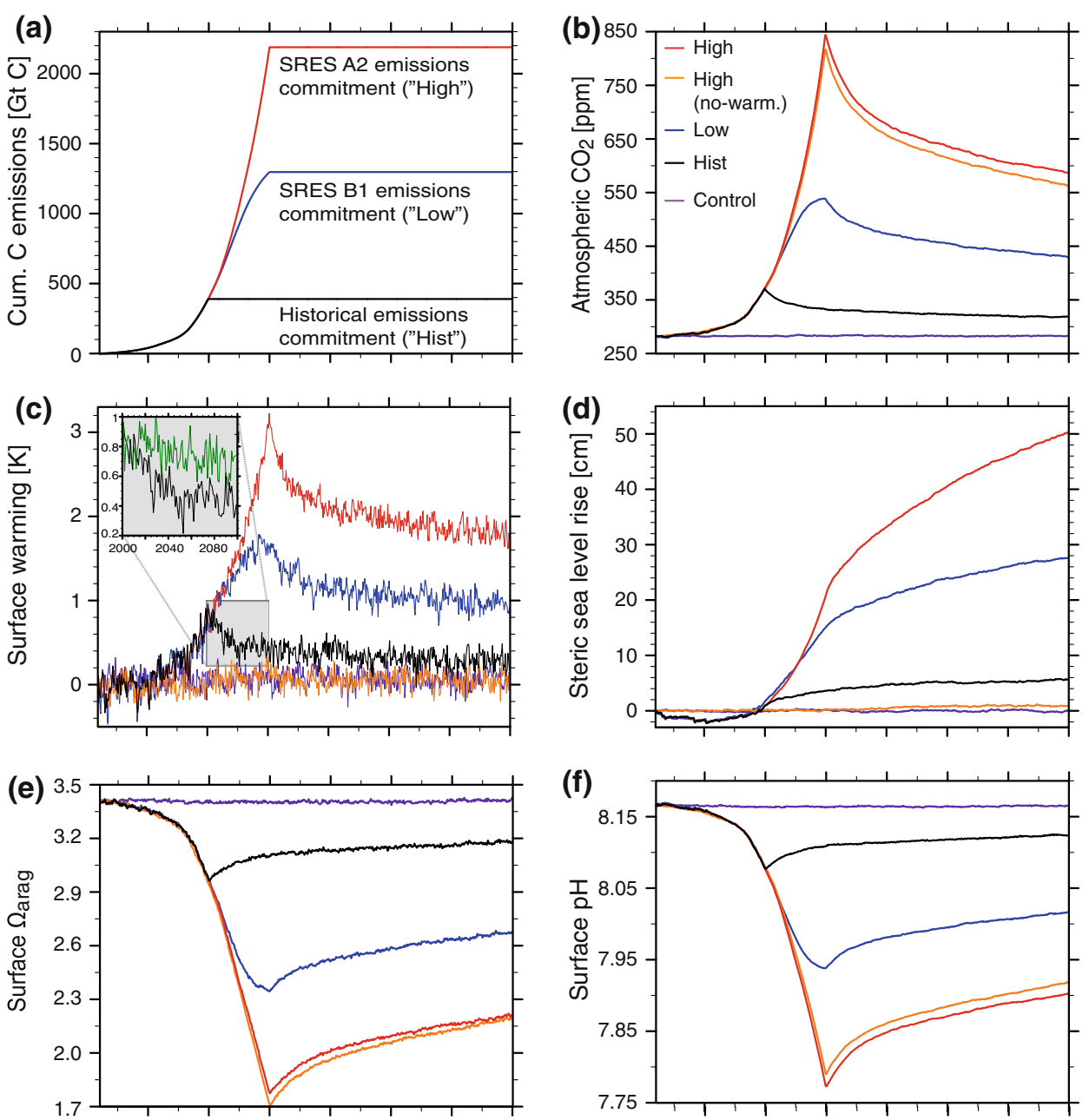

(g)

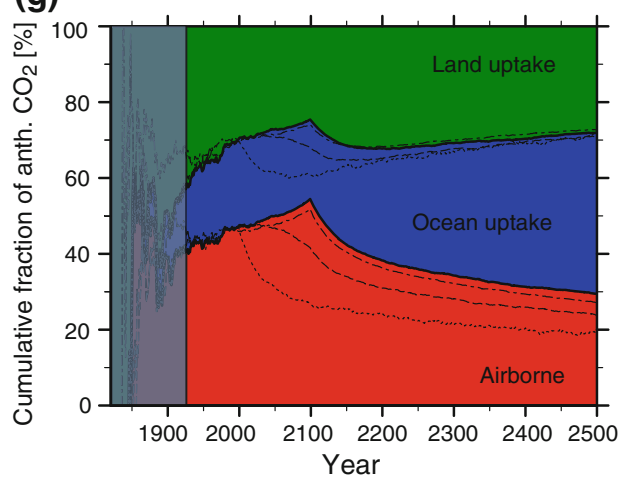

(h)

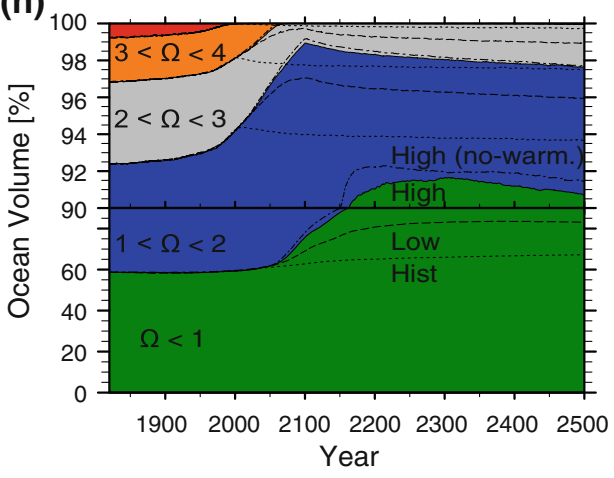

to the total GHG radiative forcing in 2100 and almost $100 \%\left(3.6 \mathrm{~W} \mathrm{~m}^{-2}\right)$ in 2500 . Radiative forcing of the shortlived GHGs such as $\mathrm{CH}_{4}, \mathrm{~N}_{2} \mathrm{O}$ or many halocarbons approaches zero within decades or a few centuries after emissions are stopped.

Atmospheric $\mathrm{CO}_{2}$ concentration increases from 282 to 844 ppm (539 ppm) by year 2100 in the High (Low) case (Fig. 1b). Thereafter, atmospheric $\mathrm{CO}_{2}$ decreases only very slowly, although carbon emissions are (unrealistically) reduced to zero in 2100. Atmospheric $\mathrm{CO}_{2}$ concentration is still twice as high by 2500 than at preindustrial times in the High case and also remains above $450 \mathrm{ppm}$ for centuries in the Low case. On the other hand, $\mathrm{CO}_{2}$ falls below $350 \mathrm{ppm}$ within a few decades in the Hist case and is $319 \mathrm{ppm}$ by 2500. Nonlinearities in the marine carbonate chemistry lead to a substantially higher fraction of $\mathrm{CO}_{2}$ emissions remaining airborne in the High than in the Hist case. 29\% are still found in the atmosphere by 2500 in the High case, in contrast to $19 \%$ in the Hist case (Fig. 1g). Clearly, the magnitude of 21st century $\mathrm{CO}_{2}$ emissions impacts the 
range of possible atmospheric $\mathrm{CO}_{2}$ concentration and radiative forcing for the coming centuries.

The long perturbation lifetime of $\mathrm{CO}_{2}$ is a consequence of the centennial to millennial overturning timescales of various carbon reservoirs. Unlike other radiative agents, anthropogenic $\mathrm{CO}_{2}$ is not destroyed by oxidation or deposited on the ground, but redistributed among the carbon reservoirs. Most of the excess carbon is taken up by the ocean and mixed down to the abyss. Ultimately, interaction with ocean sediments and the weathering cycle will remove the anthropogenic carbon perturbation from the atmosphere on timescales of millennia to hundreds of millennia (Archer et al. 1998). A substantial fraction of about $30 \%$ is taken up by the land biosphere in the High case. This uptake is mainly driven by a stimulation of photosynthesis (primary productivity) under higher atmospheric $\mathrm{CO}_{2}$ in CSM1.4-carbon and is considered to be an upper limit as productivity might be or become limited by other factors than $\mathrm{CO}_{2}$.

Global mean surface temperature anomaly peaks at $3^{\circ} \mathrm{C}$ in the High case and at $1.7^{\circ} \mathrm{C}$ in the Low case and remains around 2 and $1{ }^{\circ} \mathrm{C}$ for centuries (Fig. 1c), consistent with the low climate sensitivity of the NCAR CSM1.4. In the Hist case, global mean surface temperature remains only slightly perturbed $\left(0.2^{\circ} \mathrm{C}\right)$ by 2500 .

In all three scenarios, global mean surface temperature peaks immediately after emissions are stopped followed by an initial decadal-scale decrease. This is in contrast to $\mathrm{CO}_{2}$ only scenarios, where the decrease in global mean surface temperature is delayed after cessation of emissions (e.g. Solomon et al. 2009; Matthews and Caldeira 2008). Here, we quantify the difference between $\mathrm{CO}_{2}$ and multi-gas emission commitment scenarios for the Hist case (inset in Fig. 1c). Global mean surface temperature remains elevated in a sensitivity simulation where the radiative forcing by non- $\mathrm{CO}_{2}$ agents has been kept constant after stopping $\mathrm{CO}_{2}$ emissions in year 2000. Thus, the initial decadal-scale decrease in global mean surface temperature, almost $0.4^{\circ} \mathrm{C}$ in the Hist case, results from the decay of short-lived GHGs. The anthropogenic sulfur forcing is comparably small in our model setting (not shown). Thus, the shortterm increase in global mean surface temperature due to removal of the negative aerosol forcing after cessation of emissions is also small. The decadal-scale decrease in global mean surface temperature illustrates the potential benefits from non- $\mathrm{CO}_{2} \mathrm{GHG}$ emission mitigation.

Due to the slow heat uptake of the deep ocean global steric sea level rise continues after emissions have been stopped in 2100 for both the High and Low case and sea level is still on a rising trajectory in 2500 (Fig. 1d), consistent with the findings of others (Meehl et al. 2005; Plattner et al. 2008). In the High (Low) case, global mean sea level is projected to increase by $21 \mathrm{~cm}(15 \mathrm{~cm})$ until
2100 and by another $30 \mathrm{~cm}(13 \mathrm{~cm})$ from 2100 to 2500 . Consistently, mean ocean potential temperature increases by $0.61{ }^{\circ} \mathrm{C}$ in the High case from 2100 to 2500 , about twice the increase of $0.32^{\circ} \mathrm{C}$ from 1820 to 2100 . In other words, a large fraction of the steric sea level rise and ocean heat uptake is realized after emissions have been stopped. Even in the Hist case global mean sea level increases from 2000 to 2500 by $5 \mathrm{~cm}$ (Fig. 1d).

An important question is whether the carbon cycle-climate feedback remains as small in the coming centuries as found in 21st century scenario runs with CSM1.4-carbon or whether an increased carbon cycle-climate feedback will accelerate global warming over the coming centuries. The airborne fraction is reduced by only $2 \%$ in year 2100 in the no-warming simulation. This is at the lower end of 1-22\% obtained from models that participated in the Climate Carbon Cycle Model Intercomparison Project (Friedlingstein et al. 2006). This low sensitivity relative to other models is related to a small release of soil carbon in response to warming (Fung et al. 2005). On multi-century timescales, the climate-carbon cycle feedback slightly increases and contributes $4 \%$ to the atmospheric $\mathrm{CO}_{2}$ increase at year 2500 . The climate-carbon cycle feedback on land is highest at peak of atmospheric $\mathrm{CO}_{2}$ in year 2100; it enhances vegetation uptake, whereas it diminishes soil carbon uptake. Globally, the warming feedback on soil and vegetation partly cancel each other and remains small. The carbon cycle-climate feedback in the ocean increases from $4 \%$ (i.e. $4 \%$ more oceanic carbon uptake without global warming) in year 2000 to $8 \%$ in year 2300 . These feedbacks and underlying processes will be discussed in detail in Sect. 3.3.

In conclusion, model results and system understanding imply that atmospheric $\mathrm{CO}_{2}$ will remain high for many human generations if carbon emissions are not reduced in the coming decades. The long-term consequences of $21 \mathrm{st}$ century emissions of $\mathrm{CO}_{2}$ are fundamentally different from those of the short-lived GHGs such as $\mathrm{CH}_{4}$ and $\mathrm{N}_{2} \mathrm{O}$; anthropogenic $\mathrm{CO}_{2}$ continues to perturb the radiative balance, climate, and the biogeochemical cycles for millennia, whereas the perturbation by short-lived GHGs is removed within decades to a few centuries after emissions are stopped. Steric sea level rise continues for centuries for historical and 21 st century emissions. We also find that the carbon cycle-climate feedback remains low beyond 2100 in the NCAR CSM1.4-carbon and does not significantly accelerate global warming in our emission commitment simulations.

3.2 Projected regional changes in surface temperature, precipitation and steric sea level rise

In this section, regional changes in physical climate variables are addressed (Figs. 2,3). The internannual variability 
Fig. 2 Changes in decadal mean surface temperature for the period 2090-2099 (a, c) and for the period 2490-2499 (b, d) relative to the period 1820-1829 in the High case $(\mathbf{a}, \mathbf{b})$ and Hist case $(\mathbf{c}, \mathbf{d})$. Stippling in all panels denotes grid cells where the magnitude of change is smaller than the standard deviation from the control run. Contours are every $2^{\circ} \mathrm{C}$ (a) High: 2090 - 2099

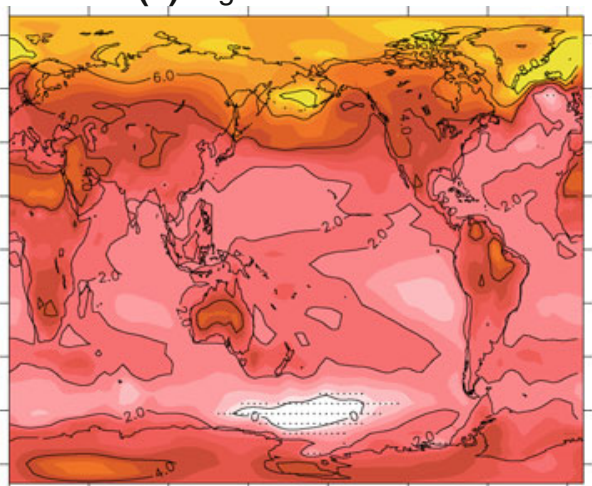

$\Delta \mathrm{T}[\mathrm{K}]$

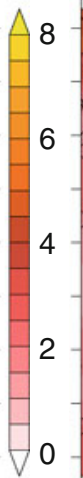

$\Delta \mathrm{T}[\mathrm{K}]$ (b) High: 2490 - 2499

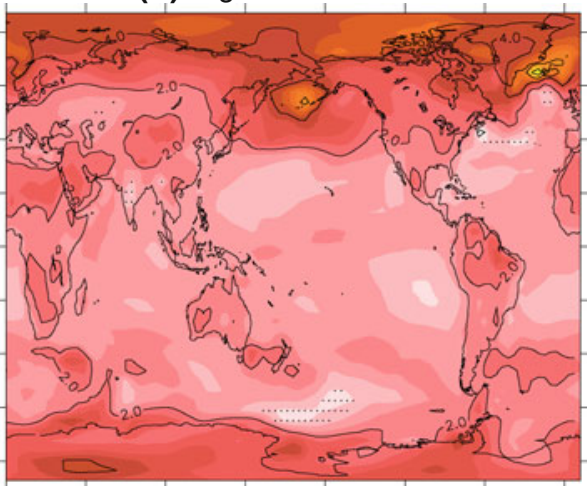

(d) Hist: 2490 - 2499
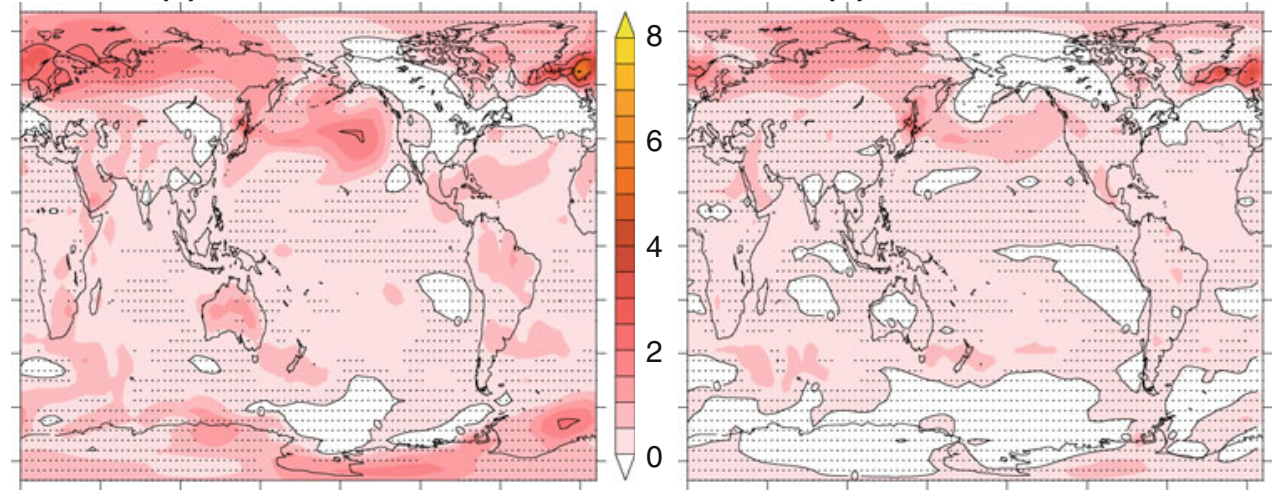

of an unforced control simulation (Fig. 4) is used to compare anthropogenically forced changes on the grid cell level. We start the discussion with the High case, because of its high signal-to-noise ratio.

The projected warming is largest in high latitudes (Fig. 2), especially over the Arctic, reflecting the important role of ice-albedo feedbacks, and greater over land than ocean, in agreement with other models (Meehl et al. 2007). Simulated temperature increase in the Arctic is $4.1^{\circ} \mathrm{C}$ in the annual mean and $5.8^{\circ} \mathrm{C}$ for the winter season by year 2500 . The relatively small warming over the Southern Ocean and in the region of North Atlantic Deep Water formation is associated with large ocean heat uptake. As the ocean takes up heat and continues to warm, the land-ocean and, thus, also the northern-southern Hemisphere contrast are reduced. The ratio of land-to-ocean and northern-tosouthern surface temperature change decreases over the period 2100-2500 from 1.66 to 1.41 and 1.69 to 1.32 , respectively. This indicates that the spatial pattern of global warming becomes slightly more uniform when emissions are reduced.

Turning to interannual variability, the model represents the magnitude and spatial pattern of temperature and precipitation variability well (Fig. 4). As in the observations, temperature variability is high north of about $40^{\circ} \mathrm{N}$ and low in the tropics. Precipitation variability is high in both model and data in the tropics and subtropics and in the
Asian monsoon regions and in southeastern and western USA and in western Europe.

The forced temperature increase is substantially higher than internal variability, measured as one standard deviation of annual values in a control simulation. Even at year 2500, surface temperature change is higher than internal variability for all grid cells except for a few cells in the Southern Pacific and Northern Atlantic (Fig. 2). Qualitatively similar but smaller warming is observed in the Low case.

Simulated precipitation shows a reduction in some arid areas and increases over most regions (Fig. 3) and in the global mean. Despite the high spatio-temporal variability of precipitation, a significant (higher than internal variability) increase in precipitation of more than $20 \%$ by year 2500 is projected for most high-latitude grid cells in the High case.

Steric sea level rise is projected to have substantial spatial variability (Fig. 3). Differences between regions are of similar order as global average sea level rise. However, sea level change is positive almost everywhere in year 2500 in the High case. Thermosteric sea level change is significantly higher in the North Atlantic than in the North Pacific, reflecting the formation of deep water, enhanced ventilation and heat uptake. Sea level rise in the North Atlantic is damped through halosteric anomalies, whereas sea level change in the Arctic Ocean is partly driven by 
Fig. 3 a-d Changes in decadal mean precipitation for the period 2090-2099 (a, b) and for the period 2490-2499 (c, d) relative to the period $1820-1829$ in the High case $(\mathbf{a}, \mathbf{c})$ and the Hist case (b, d), respectively. e-h Changes in steric sea level for the same periods. Stippling in all panels denotes grid cells where the magnitude of change is smaller than the standard deviation from the control run. Contours in $(\mathbf{e}-\mathbf{h})$ show the halosteric contribution to the total steric sea level rise and are every $10 \mathrm{~cm}$
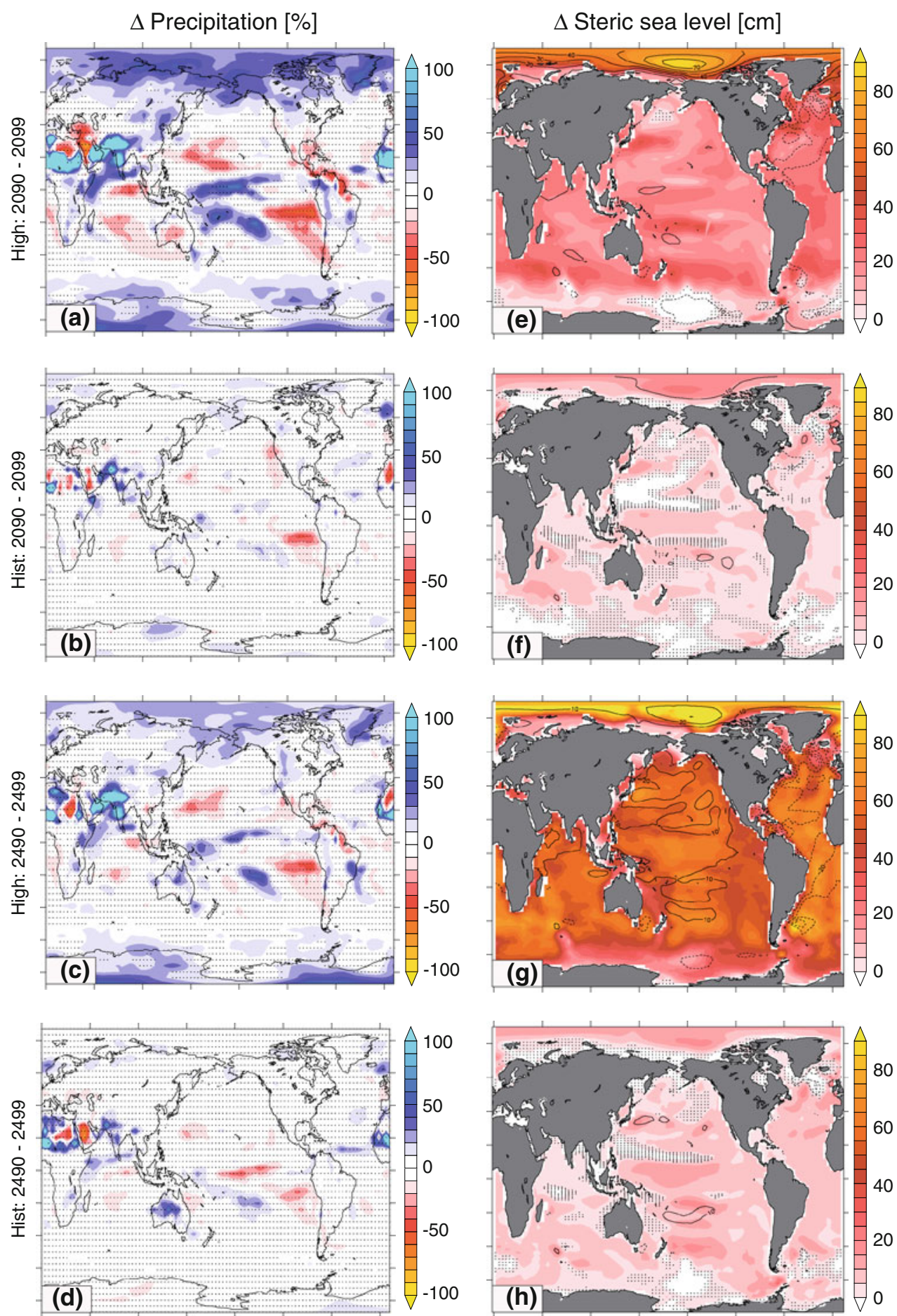

halosteric changes due to increasing freshwater input from additional melting of sea ice and enhanced precipitation. Similar as for surface temperature, steric sea level rise is larger than modeled internal variability at almost each grid cell in year 2500 for both the High and the Low case.

Turning to the Hist scenario, we observe a remarkable qualitative difference compared to the High and Low case. Regional surface temperature and precipitation return towards the preindustrial equilibrium after emissions have been stopped (Figs. 2, 3). Surface temperature changes become smaller than internal variability for most land (82\%), including Eurasia and North America, and most of the ocean grid cells $(73 \%)$. Signals larger than internal variability still persist in parts of tropical Africa, South America, and around Indonesia (Fig. 2). Precipitation changes become smaller than internal variability in almost 
Fig. 4 Simulated versus observation-based interannual variability over land. (a, c) Simulated interannual variability in surface temperature and precipitation obtained by computing the standard deviation of annual mean values from the unforced control simulation. (b, d) Observation-derived interannual variability from the Climatic Research Unit surface air temperature and precipitation dataset (Brohan et al. 2006; Mitchell and Jones 2005). Data have been regridded on the NCAR model grid and detrended by a smoothing spline with a cut-off period of 20 years for century-scale trends before computing the standard deviations; the results are not sensitive to the exact choice of the cut-off period between 10 and 80 years (a) Temperature: Model

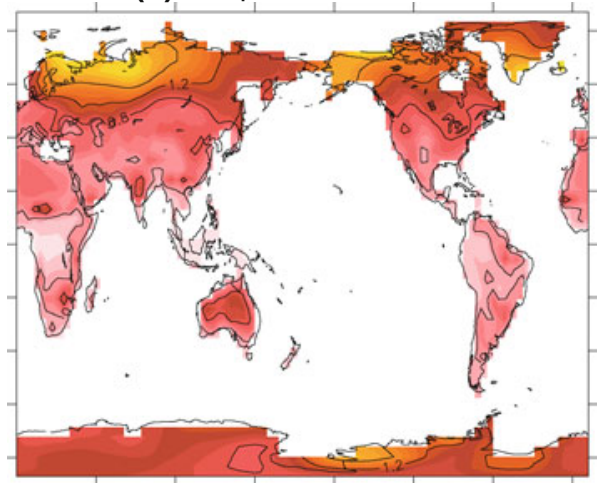

(c) Precipitation: Model

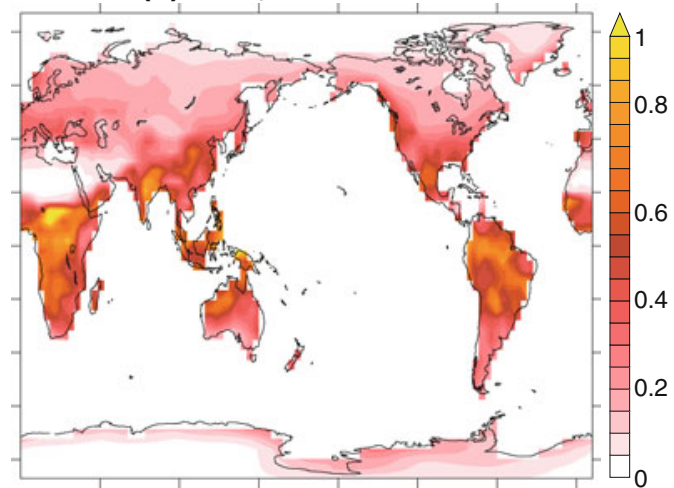

(b) Temperature: Observations

[K]
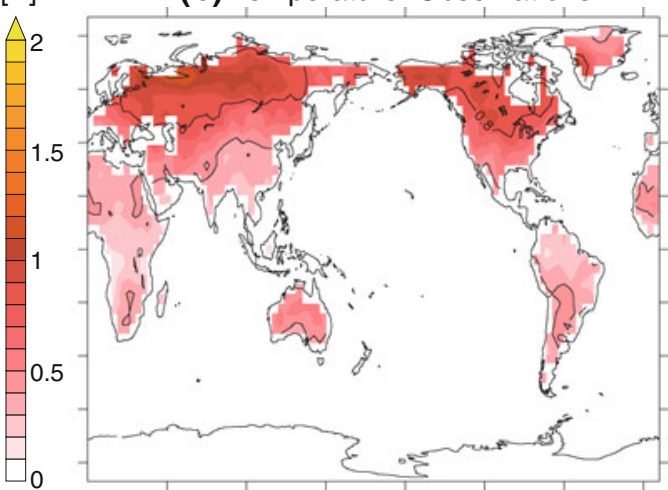

(d) Precipitation: Observations

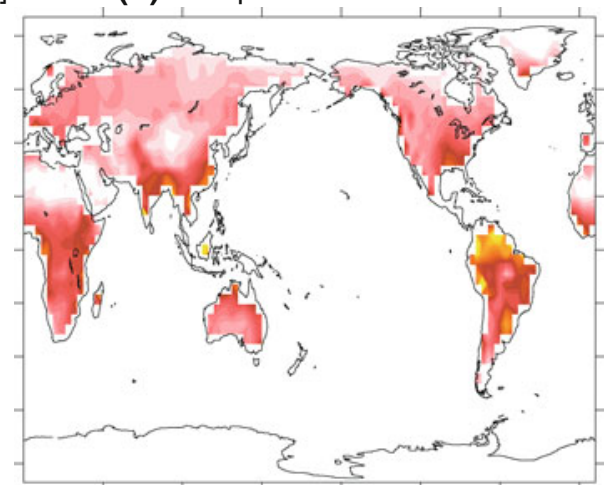

all grid cells (97\%; Fig. 3). This indicates that perturbations in precipitation and temperature associated with 19th and 20th century emissions become comparable to unforced, internal variability in most regions within the next centuries. Simulated sea level rise remains higher than simulated internal variability in many regions (Fig. 3) as internal interannual variability is small.

In conclusion, 21st century $\mathrm{CO}_{2}$ emissions on the order of several hundred to a few 1,000 gigatons of carbon will perturb surface temperature, precipitation and sea level irreversibly on human timescales. In contrast, the impact of historical emissions on temperature and precipitation is largely reversible within centuries in most regions in the sense that the regional anthropogenic perturbation becomes smaller than internal unforced regional variability in our model.

\subsection{Projected regional changes in ocean} and land carbon inventories, mechanisms and warming feedbacks

\subsubsection{Land}

Next, changes in land carbon inventories are discussed with a focus on the long-term evolution and climate feedbacks. Analyzes of land carbon stock changes as simulated by the
CSM1.4-carbon model for the 21st century are already provided elsewhere (Fung et al. 2005; Friedlingstein et al. 2006). Here, simulations and analysis period are extended beyond 2100 and the regional response of vegetation and soils to increasing $\mathrm{CO}_{2}$ and climate change are investigated individually.

High land uptake is simulated in the tropical and northern mid-to-high latitude forests (Fig. 5a,b) predominantly in response to increasing atmospheric $\mathrm{CO}_{2}$ and related $\mathrm{CO}_{2}$ fertilization of net primary productivity (NPP). NPP and changes in vegetation carbon evolve largely in parallel with changes in atmospheric $\mathrm{CO}_{2}$. Vegetation carbon peaks at all latitudes within five decades after the emission stop and the $\mathrm{CO}_{2}$ peak. The relatively slow turnover of soil carbon, particularly in cold regions, lead to a delayed response in soil and total carbon stock changes to the $\mathrm{CO}_{2}$ forcing. For example in the High case, the peak in total carbon inventory is projected 70 years later in the tropics and 130 years later at northern high latitudes than the $\mathrm{CO}_{2}$ peak (Fig. 5b). Total land carbon uptake amounts to $704 \mathrm{GtC}$ at peak and to $611 \mathrm{GtC}$ by year 2500 . Roughly $58 \%$ of the additional carbon is sequestered by vegetation, the rest by soils.

The CSM1.4 has a low sensitivity of global terrestrial storage to climate change and a low global climate-land uptake feedback. Global land uptake is lower by up to $5 \%$ 
(a) 2490 - 2499: $\Delta$ Carbon $\left[\mathrm{kg} \mathrm{m}^{-2}\right]$

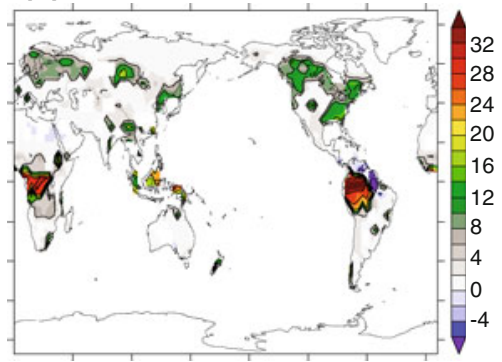

(b) $\Delta$ Carbon $\left[\mathrm{kg} \mathrm{m}^{-2}\right]$

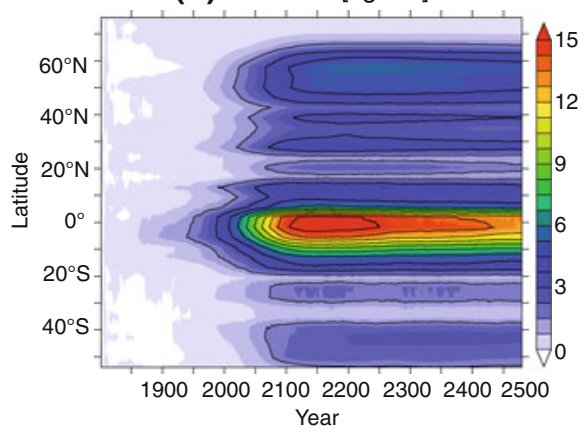

(c) Climate-carbon gain [\%]

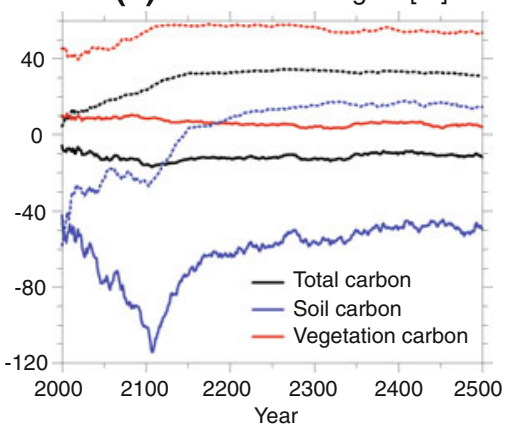

Fig. 5 (a) Changes in decadal mean total terrestrial carbon inventories for the period 2490-2499 relative to the period 1820-1829 in the High case. (b) Projected evolution of the annual mean zonally-averaged carbon inventories in the High case. (c) Projected evolution of the climate-carbon gain $(g=1-\Delta \mathrm{C}$ (no-warming) $/ \Delta \mathrm{C}$ (High case) $)$, where $\Delta \mathrm{C}$ is the difference in carbon stocks from preindustrial levels. Positive (negative) values denote more (less) uptake with global warming. Solid lines in (c) correspond to the tropics $\left(20^{\circ} \mathrm{N}: 20^{\circ} \mathrm{S}\right)$ and dashed lines correspond to the northern high latitudes $\left(40^{\circ} \mathrm{N}: 70^{\circ} \mathrm{N}\right)$. Contours in (a) and (b) are every 5 and $1.5 \mathrm{~kg} \mathrm{~m}^{-2}$, respectively

in the High case than in the no-warming simulation. The small global sensitivity results from opposing regional responses as illustrated by the evolution of the climatecarbon gain in different regions and reservoirs (Fig. 5c). The climate-carbon gain describes the percentage gain of vegetation carbon $g_{\mathrm{veg}}$, and soil carbon $g_{\text {soil }}$ in the High case with global warming relative to the corresponding simulations without warming:

$g=(1-\Delta \mathrm{C}($ no-warming $) / \Delta \mathrm{C}($ High case $))$,

where $\Delta \mathrm{C}$ is the difference in carbon stocks from preindustrial levels. A positive $g$ implies more carbon uptake from the atmosphere under warming and thus a negative climate-carbon cycle feedback.

The difference in land sinks in the simulations result from differing sensitivities of NPP and respiration to changes in $\mathrm{CO}_{2}$, light, temperature, and moisture regimes, and their competitive effects on regional carbon inventories in vegetation and soils (Fung et al. 2005). Warming and moistening accelerate NPP and increase vegetation biomass and carbon fluxes to soils, but shortens soil turnover time through increased soil respiration rates. The higher atmospheric $\mathrm{CO}_{2}$ in the High case relative to the no-warming case implies more $\mathrm{CO}_{2}$ fertilization tending to increase terrestrial storage. The interplay of these mechanisms leads to a complex spatiotemporal evolution of the climate-carbon gain for vegetation and soils in our multi-century simulations.

In northern mid and high latitudes $\left(40-70^{\circ} \mathrm{N}\right)$, soil moisture and temperature increase and growing conditions become more favorable. Total carbon uptake is higher by $10-30 \%$ in the High relative to the no-warming case (Fig. 5c). Uptake by vegetation is about $55 \%$ larger in the High case than in the nowarming case. The reduction in soil turnover time and the increase in the carbon flux to litter and soils have opposite impacts on soil carbon and $g_{\text {soil }}$ changes sign over time. Cumulative soil carbon uptake is lower by one third in year 2000 in the High than in the no-warming case. Then, $g_{\text {soil }}$ increases over the coming two centuries to stabilize at around $15 \%$. The increased flux from vegetation to soils overrules in the long-term the effect of reduced soil turnover times.

In the tropics, less carbon is stored under global warming. Large areas in northeastern South America and in parts of Indonesia suffer from decreased soil moisture and higher temperature leading to lower NPP and vegetation carbon uptake in the High case. However, overall carbon storage in tropical vegetation is about 5\% higher in the High than in the no-warming case, as growing conditions improve with warming and/or moistening in west equatorial Africa and west equatorial South America. In contrast, tropical soils absorb by as much as $50 \%$ less carbon in the High than in the nowarming case. Taken together, competing processes and system time lags results in different evolution of the climateland carbon feedbacks in different regions and for different land components. In the NCAR CSM1.4, these processes happen to largely cancel each other resulting in a small global terrestrial carbon cycle-climate feedback.

\subsubsection{Ocean}

Carbon uptake by the ocean continues over centuries, in contrast to uptake by land. In earlier publications related to marine oxygen variability, ocean acidification and marine productivity, we have discussed changes in physical properties such as temperature, salinity, circulation and stratification, changes in marine biological processes such 
as production and export of organic carbon, and changes in biogeochemical tracers such as oxygen. These studies present results from simulations with the NCAR CSM1.4carbon over the industrial period and this century (Frölicher et al. 2009; Steinacher et al. 2009a, b). Sea surface temperature and stratification increases, surface nutrient concentration and marine productivity decreases in most regions under the SRES A2 and B1 scenarios. The Atlantic Meridional Overturning Circulation (AMOC) weakens and becomes shallower and mixed layer depth decreases in the northern North Atlantic. Here, we discuss now the ocean uptake of $\mathrm{CO}_{2}$ and the impact of climate change in detail and attribute the multi-century scale changes in the oceanic distribution of dissolved inorganic carbon (DIC) to different mechanisms.

The rate limiting step for ocean uptake of anthropogenic carbon is surface-to-deep transport with typical timescales of decades for thermocline ventilation and centuries for deep ocean overturning. Ocean chemistry, in particular the distribution of the Revelle factor, describing the relative increase in $\mathrm{CO}_{2}$ partial pressure per relative increase in DIC, and ocean volume determine the overall uptake capacity for excess carbon. Warm water has a lower Revelle factor than cold water resulting in a higher uptake capacity of excess carbon per volume. Climate-carbon cycle feedbacks such as those related to changes in temperature, stratification, and ocean circulation, and to the marine biological cycle further modify the distribution of natural and anthropogenic carbon (e.g. Joos et al. 1999; Plattner et al. 2001). We use again results from the High case and the related no-warming case to illustrate the model response.

The highest column inventories of DIC in the ocean are simulated in the region of deep water formation in the North Atlantic and in the area of the well-ventilated Antarctic Intermediate Water around $40^{\circ} \mathrm{S}$ in year 2100 (Fig. 6a). Concentrations decline from surface to the deep, consistent with reconstructions of anthropogenic carbon (Sabine et al. 2004). DIC concentration decreases after cessation of emissions at the surface, but continues to increase at depth due to continued surface-to-deep exchange (Figs. 7, 8). In 2500 (High case; Fig. 6b), column inventories and concentrations are more uniform in the Atlantic and the Southern Ocean, whereas concentrations and inventories are still low in the slowly-ventilated waters of the deep Indian and Pacific Ocean, consistent with the centennial-to-millennial mixing timescales inferred from the observed radiocarbon distribution (Key et al. 2004; Müller et al. 2006).

The $\mathrm{CO}_{2}$ air-to-sea flux increases with increasing atmospheric $\mathrm{CO}_{2}$ with interesting spatial variations. The Southern Ocean $\left(<45^{\circ} \mathrm{S}\right)$ turns from a source to a sink of atmospheric $\mathrm{CO}_{2}$ at around year 2000, consistent with databased reconstructions of contemporary and preindustrial air-sea fluxes (Gerber et al. 2009; Gruber et al. 2009). The global air-to-sea flux peaks with atmospheric $\mathrm{CO}_{2}$ when emissions are stopped and decreases afterwards to become again a sink in the Southern Ocean, albeit smaller than at preindustrial time. In most regions, air-to-sea flux is still higher at 2500 than at the start of the simulation. Thus, the ocean is still taking up anthropogenic carbon. Remarkably, the northern North Atlantic sink flux is smaller in 2500 than at 1820 and a few grid cells around $60^{\circ} \mathrm{N}$ even show $\mathrm{CO}_{2}$ outgassing by 2500 . In other words, the perturbation flux (relative to preindustrial) is from the ocean to the atmosphere in the northern North Atlantic. Similarly, the perturbation flux has also reversed in the northeastern Pacific. This negative perturbation flux is explained by the lower uptake capacity (higher Revelle factor) of cold waters relative to warm water that tends to drive a perturbation flux from the warm equatorial ocean to the cold high-latitude ocean when the ocean-atmosphere system approaches a new $\mathrm{CO}_{2}$ equilibrium (Siegenthaler and Joos 1992). This negative perturbation flux is even more pronounced in the simulation without global warming.

Climate change affects the uptake of $\mathrm{CO}_{2}$ and the distribution of dissolved inorganic carbon (DIC) within the ocean. Following Plattner et al. (2001), we attribute
Fig. 6 Model estimates of decadal mean oceanic column inventories of anthropogenic carbon (a) for the period 2090 2099 and (b) for the period 2490-2499 relative to the period 1820-1829. Contours are every $50 \mathrm{~mol} \mathrm{~m}^{-2}$ (a) 2090 -2099: $\Delta \mathrm{DIC}\left[\mathrm{mol} \mathrm{m}^{-2}\right]$

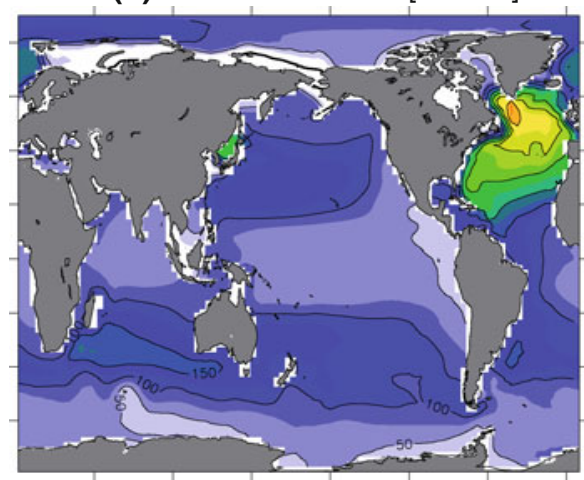

(b) $2490-2499: \Delta \mathrm{DIC}\left[\mathrm{mol} \mathrm{m}^{-2}\right]$

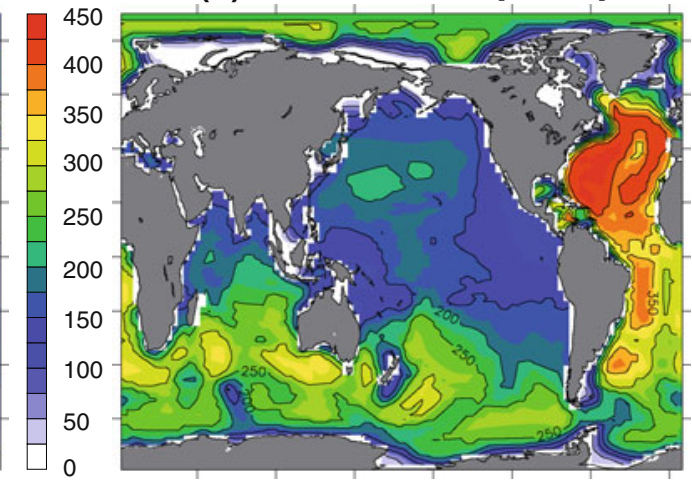


Fig. 7 Meridional sections through the Atlantic including the Arctic Ocean showing simulated zonal and decadal mean changes in salinitynormalized DIC (sDIC) for the period 2090-2099 (left) and the period 2490-2499 (right) compared to the period 1820 1829 in the High case. Changes in (a) sDIC due to gas exchange only $\left(\Delta \mathrm{sDIC}_{\text {gas, baseline }}\right)$ from the no-warming simulation,

(b) $\Delta \mathrm{sDIC}_{\text {bio }}$ due to the internal reorganization of the organic matter cycle and $\mathrm{CaCO}_{3}$ cycle, and (c) $\Delta$ sDIC $_{\text {gas,feedback }}$ due to the changes in air-sea gas exchange. sDIC inventory changes (GtC) are indicated at the bottom-left corner of each panel. Note different scales

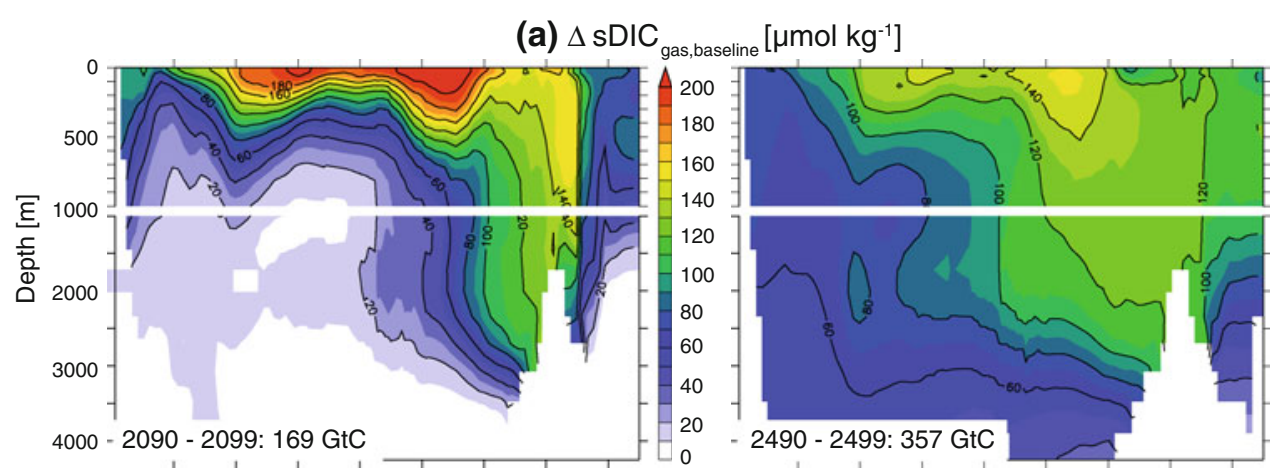

(b) $\Delta \mathrm{sDIC}_{\mathrm{bio}}\left[\mu \mathrm{mol} \mathrm{kg}{ }^{-1}\right]$

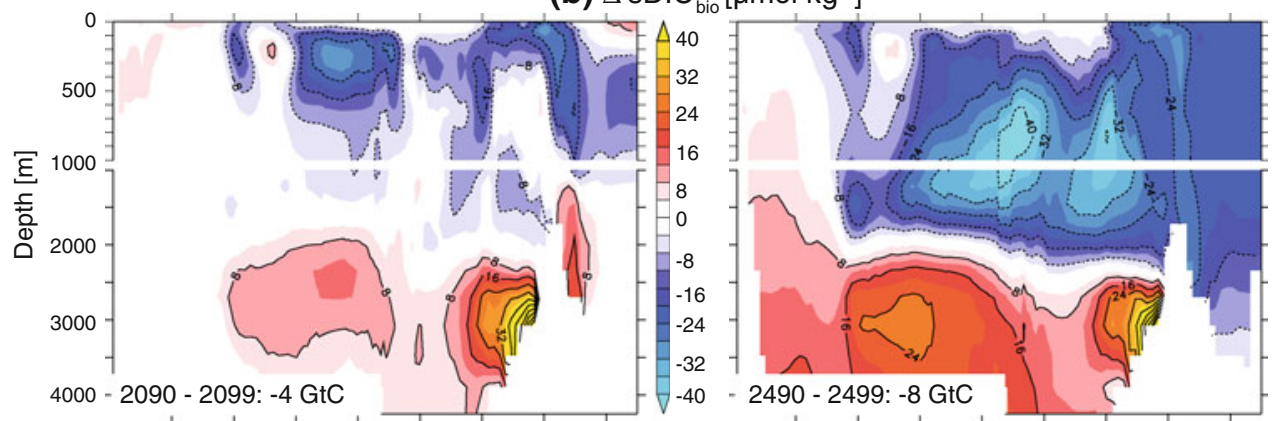

(c) $\triangle \mathrm{SDIC}$ $\left[\mu \mathrm{mol} \mathrm{kg}{ }^{-1}\right]$

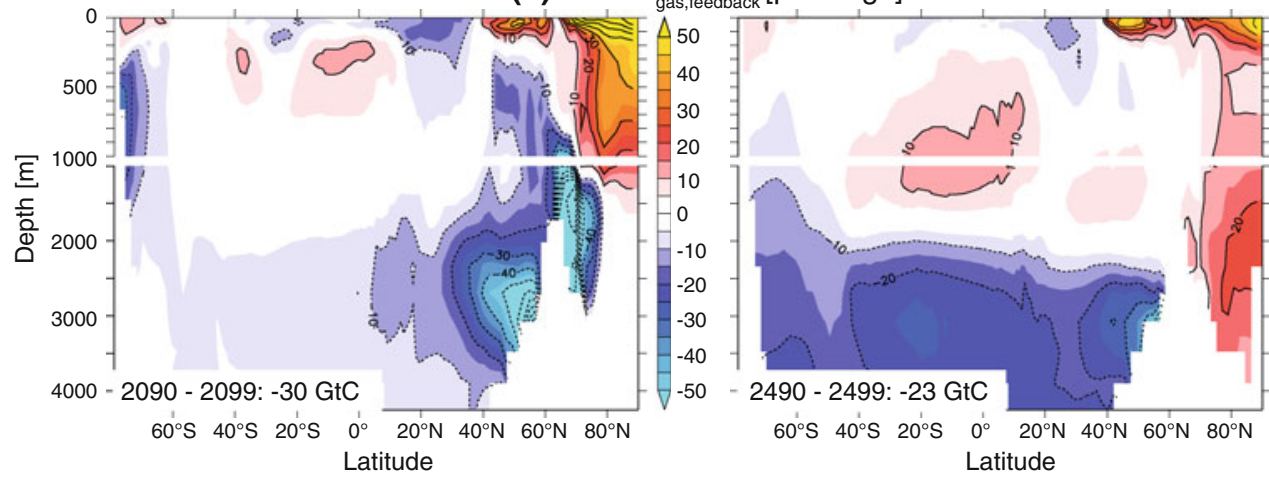

the changes in salinity normalized DIC as simulated in the High case, $\Delta \mathrm{sDIC}_{\text {tot }}$ to (1) air-sea exchange driven by rising $\mathrm{CO}_{2}$ only, $\Delta \mathrm{sDIC}_{\text {gas,baseline, }}$, (2) to changes in the marine biological cycle, $\Delta \mathrm{sDIC}_{\mathrm{bio}}$, and (3) to the climate induced changes in $\mathrm{CO}_{2}$ uptake, $\Delta \mathrm{sDIC}$ gas,feedback (Figs. 7, 8). By far the largest contribution to the simulated change in DIC is directly driven by the increase in atmospheric $\mathrm{CO}_{2}$. This component is quantified by the nowarming simulation. The spatial and temporal evolution of

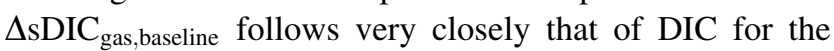
High case discussed two paragraphs earlier.

Climate change causes a reorganization of the marine organic matter cycle and of the calcite cycle in the model. This reorganization is driven by changes in circulation and water mass distribution and changes in productivity and export of organic matter and calcite. The latter are related to changes in physical parameters and nutrient availability
(Steinacher et al. 2009b). Changes in DIC related to changes in marine productivity and remineralization of organic matter and calcite are linearly linked to changes in phosphate $\left(\triangle \mathrm{PO}_{4}\right)$ and alkalinity $(\triangle \mathrm{ALK})$ by Redfield ratios in the NCAR CSM1.4-carbon. This allows us to quantify the influence of this reorganizations on DIC as:

$\Delta \mathrm{sDIC}_{\mathrm{bio}}=117 * \Delta \mathrm{sPO}_{4}+0.5 *\left(\Delta \mathrm{sALK}+16 * \Delta \mathrm{sPO}_{4}\right)$.

The first right hand term represents the reorganization of the organic matter cycle and 117 is the carbon-to-phosphate Redfield ratio. The second right hand term represents the reorganization of the calcite cycle as obtained from simulated changes in alkalinity and phosphate.

Climate change causes also a reduction in the uptake flux of atmospheric $\mathrm{CO}_{2}$ relative to the simulation with no climate change. This reduction is linked to sea surface 
Fig. 8 Following Fig. 7 for the Pacific Ocean

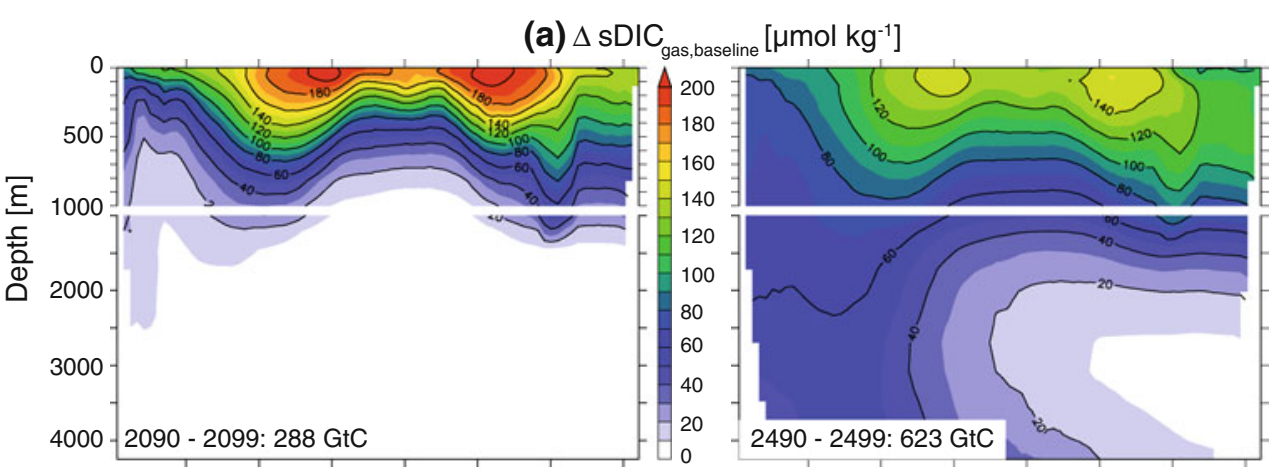

(b) $\Delta \mathrm{sDIC}_{\text {bio }}\left[\mu \mathrm{mol} \mathrm{kg}{ }^{-1}\right]$

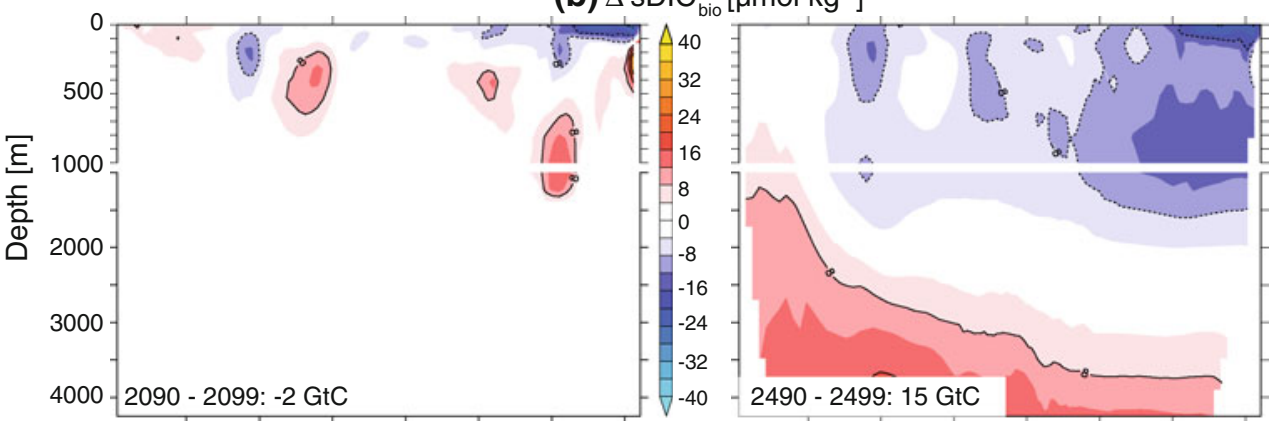

(c) $\Delta \mathrm{SDIC}_{\text {gas feedback }}\left[\mu \mathrm{mol} \mathrm{kg}{ }^{-1}\right]$

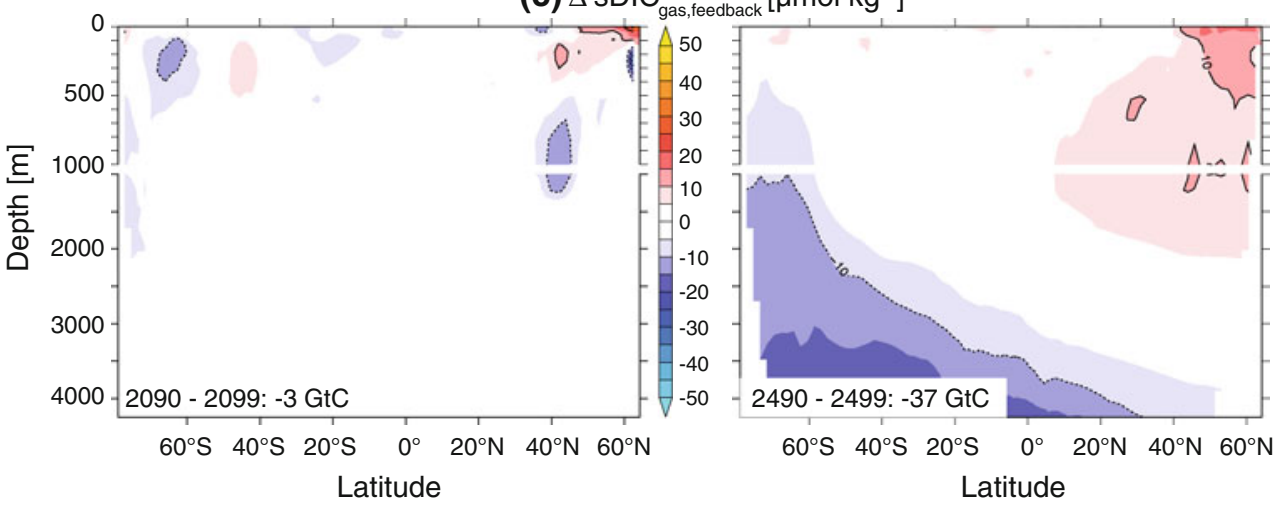

warming, decreasing $\mathrm{CO}_{2}$ solubility, to a slowed circulation and surface-to-deep transport of anthropogenic carbon, to a reduction of nutrients and carbon linked to changes in the marine biological cycle, and to sea ice retreat, permitting additional air-sea gas exchange. The first two effects reduce carbon uptake, while the latter mechanisms tend to increase uptake. The influence on DIC of climate related changes in $\mathrm{CO}_{2}$ uptake is quantified by difference:

$$
\begin{aligned}
\Delta \mathrm{sDIC}_{\text {gas, feedback }}= & \Delta \mathrm{sDIC}_{\text {tot }}-\Delta \mathrm{sDIC}_{\mathrm{gas}, \text { baseline }} \\
& -\Delta \mathrm{sDIC}_{\text {bio }} .
\end{aligned}
$$

The reorganization of the organic matter cycle and that of the calcite cycle contribute about equally to $\Delta \mathrm{sDIC}_{\text {bio }}$. In $2100, \Delta \mathrm{sDIC}_{\mathrm{bio}}$ (and phosphate and alkalinity) shows a dipole structure in the North Atlantic with negative concentrations in the equatorial and North Atlantic thermocline, and positive concentrations below 2,000 m, particular north of $40^{\circ} \mathrm{N}$. This change is linked to a decrease in the strength and penetration of the AMOC, increased stratification and reduced surface-to-deep exchange which increases the accumulation of nutrients and carbon at depth. The AMOC (maximum in the North Atlantic stream function from 20 to $50^{\circ} \mathrm{N}$ and 500 to 2,000 $\mathrm{m}$ depth) is projected to be $13 \%$ lower in year 2500 than at preindustrial time in the High case. Changes in phosphate and alkalinity, and thus in $\Delta \mathrm{sDIC}_{\text {bio }}$ in the Pacific are generally small in 2100 . By $2500, \Delta \mathrm{sDIC}_{\text {bio }}$ has further increased in the deep Atlantic, but also in the deep Pacific, while $\Delta \mathrm{sDIC}_{\mathrm{bio}}$ in the thermocline has become more negative. These long-term changes are connected to a slowed ventilation of the deep ocean and a related accumulation of carbon, nutrients, and alkalinity at depth. 
The distribution of $\Delta \mathrm{sDIC}_{\text {gas,feedback }}$ mirrors to some extent the distribution of $\Delta \mathrm{sDIC}_{\mathrm{bio}}$ in the deep ocean. The reduction in the AMOC and the slowed deep ocean ventilation results in a less efficient surface-to-deep transport of excess carbon and thus to negative concentrations of $\Delta \mathrm{sDIC}_{\text {gas,feedback }}$ below $2,000 \mathrm{~m}$. As with $\Delta \mathrm{sDIC}$ bio , these changes accrue over the 21 st century in the North Atlantic but only on a multi-century timescale in the deep South Atlantic and deep Pacific. Changes in $\Delta \mathrm{sDIC}_{\text {gas,feedback }}$ in the thermocline and surface ocean are comparably smaller. Exceptions are the Arctic ocean and to a lesser extent the northern North Pacific, where reduced sea ice cover leads to an enhanced uptake of carbon under global warming. The slower surface-to-deep exchange and reduced surface nutrient concentrations in the northern North Atlantic also provoke an additional accumulation of carbon at the surface by air-sea exchange.

In summary, the increase in atmospheric $\mathrm{CO}_{2}$ is the most important driver of changes in dissolved inorganic carbon in the ocean. Climatic feedbacks related to the reorganization of the organic matter cycle and changes in air-sea $\mathrm{CO}_{2}$ fluxes lead to notable modifications in the simulated distribution of DIC, particularly in the deep ocean and the Arctic. The deep ocean is still far away from equilibrium with the atmospheric perturbation by year 2500 and the ocean continues to absorb anthropogenic carbon from the atmosphere. These results complement the findings of Schmittner et al. (2008). They showed in simulations with an EMIC the delayed response of the climate system and the carbon cycle to a reduction in carbon emissions on a global scale.

\subsection{Projected ocean acidification}

One concern of anthropogenic carbon emissions is its impact on marine life. Recent studies indicate that ocean acidification by the uptake of $\mathrm{CO}_{2}$ has adverse consequences for many marine organisms via decreased $\mathrm{CaCO}_{3}$ saturation, affecting calcification rates, and via disturbance to acid-base physiology (Fabry et al. 2008). Vulnerable organisms that build shells and other structures of $\mathrm{CaCO}_{3}$ in the relatively soluble form of aragonite or high-magnesium calcite, but also organisms that form $\mathrm{CaCO}_{3}$ in the more stable form of calcite may be affected. Undersaturation as projected for the high latitude ocean (Steinacher et al. 2009a; Orr et al. 2005) has been found to affect for example pteropods, an abundant group of species forming aragonite shells (Orr et al. 2005). Changes in saturation are also thought to affect coral reefs (De'ath et al. 2009; Hoegh-Guldberg et al. 2007; Langdon and Atkinson 2005; Kleypas et al. 1999). The impacts are likely not restricted to ecosystems at the ocean surface, but potentially also affect life in the deep ocean such as the extended deep water coral systems and ecosystems at the ocean floor. The degree of sensitivity varies among species and some taxa may show enhanced calcification at $\mathrm{CO}_{2}$ levels projected to occur over the 21 st century (Iglesias-Rodriguez et al. 2008). Indicators of ocean acidification are $\mathrm{pH}$ and the saturation state of sea water with respect to aragonite, $\Omega_{\mathrm{arag}}$ (or calcite, $\Omega_{\text {calc }}$ ). When $\Omega_{\text {arag }}$ is less than one (or $100 \%$ ), water is undersaturated and aragonite dissolves to calcium and carbonate ions in the absence of protective mechanisms. $\Omega_{\text {arag }}$ larger than $100 \%$ corresponds to supersaturation. Supersaturated conditions are possible, as the activation energy to form aragonite is high. On an annual average the surface ocean is currently supersaturated everywhere with respect to aragonite with high supersaturation in the tropics and subtropics and low supersaturation in the high latitude ocean (Fig. 9a). Saturation decreases with depth and the deep ocean is undersaturated (Fig. 10).

Global mean surface $\Omega_{\text {arag }}$ is projected to decrease from a preindustrial mean of 341 to $235 \%$ in the Low case and to $183 \%$ in the High case until 2100 (Fig. 1e). Likewise, global mean surface $\mathrm{pH}$ decreases from 8.17 to 7.94 and to 7.79, respectively (Fig. 1f). Global mean surface $\mathrm{pH}$ and $\Omega_{\text {arag }}$ increase only slowly and in parallel with the atmospheric $\mathrm{CO}_{2}$ decrease after carbon emissions are stopped.

Surface ocean $\Omega_{\text {arag }}$ and $\mathrm{pH}$ decrease at all latitudes under rising atmospheric $\mathrm{CO}_{2}$ (Fig. 9). Largest surface changes are found in the tropics and subtropics for $\Omega_{\text {arag }}$ and in the Arctic for $\mathrm{pH}$. In the High case, $\Omega_{\text {arag }}$ in the tropics and subtropics decreases from a saturation state of more than $400 \%$ at preindustrial times to saturation below $250 \%$ at the end of the 21 st century. Tropical and subtropical surface waters remain below $300 \%$ saturation until 2500 . Climate change has a small influence on ocean acidification and alkalinity in the surface ocean, except for the Arctic. Differences in surface $\Omega_{\mathrm{arag}}, \mathrm{pH}$ and in alkalinity are generally small between the High case with global warming and the no-warming simulation, consistent with earlier findings (Steinacher et al. 2009a; Cao et al. 2007). Although experimental evidence remains scarce, these projected low saturation state in combination with other stress factors such as increased temperature poses the risk of an irreversible destruction of warm water coral reefs.

Arctic surface water starts to become undersaturated with respect to aragonite within the next decade and undersaturation becomes widespread in the Southern Ocean on annual and zonal average for an atmospheric $\mathrm{CO}_{2}$ concentration around $580 \mathrm{ppm}$ (Fig. 9). Climate change amplifies the decrease in annual mean $\Omega_{\text {ara }}$ in the Arctic Ocean by $22 \%$ mainly due to surface freshening, causing alkalinity to decrease by more than $0.1 \mathrm{mmol} l^{-1}$ over this century in the High case, and increased uptake of anthropogenic carbon in response to sea ice retreat and possible land-ice melting. A detailed quantitative discussion of the Arctic changes and underlying mechanisms is provided by 

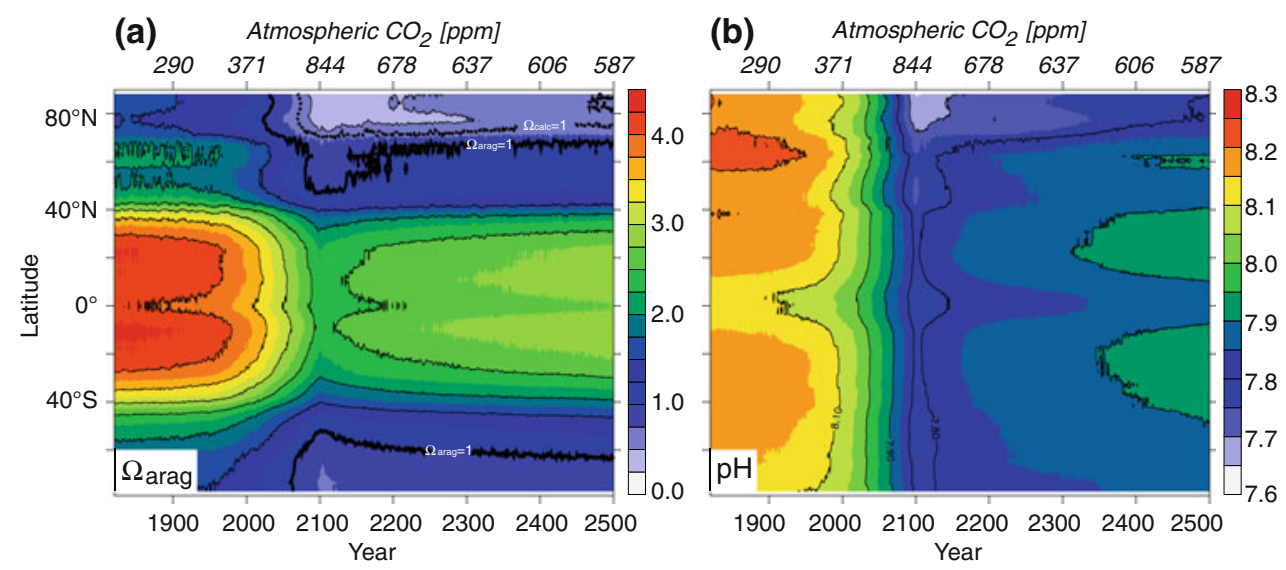

Fig. 9 Simulated evolution of zonal and annual mean (a) surface $\Omega_{\text {arag }}$ and (b) surface $\mathrm{pH}$ in the High case as function of time and of the annual mean atmospheric $\mathrm{CO}_{2}$ mixing ratio. Solid and dashed lines in (a) correspond to the aragonite $\left(\Omega_{\text {arag }}=100 \%\right)$ and calcite $\left(\Omega_{\text {calc }}=100 \%\right)$ saturation horizon, respectively

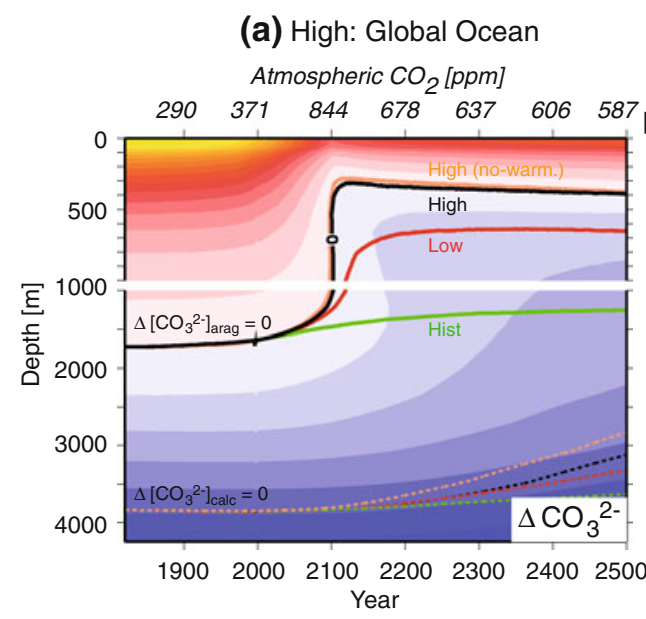

Fig. 10 Simulated evolution of annual mean aragonite saturation state in the High case, as indicated by excess $\mathrm{CO}_{3}^{2-}\left(\Delta \mathrm{CO}_{3}^{2-}=\right.$ $\left.\mathrm{CO}_{3}^{2-} \cdot\left(1-1 / \Omega_{\text {arag }}\right)\right)$, at different depths for the Global Ocean (a) and the Arctic Ocean (b). Arctic Ocean is defined by waters north of $65^{\circ} \mathrm{N}$, except the Labrador Sea and the Greenland, Iceland, and Norwegian Sea $\left(<80^{\circ} \mathrm{N}\right.$ and $\left.35^{\circ} \mathrm{W}-18^{\circ} \mathrm{E}\right)$. Solid lines correspond to

Steinacher et al. (2009a) for the 21 st century. Our results demonstrate, that the undersaturation in the Arctic Ocean is maintained over centuries in the High and the Low case, again underscoring the long-term impacts of 21 st century carbon emissions.

The response of Arctic surface $\Omega_{\text {arag }}$ and the change in air-sea $\mathrm{CO}_{2}$ partial pressure difference $\left(\Delta \mathrm{pCO}_{2}\right)$ to atmospheric $\mathrm{CO}_{2}$ forcing further illustrates system time lags and the intricate coupling between biogeochemical cycles and climate (Fig. 11). On global average, $\Delta \mathrm{pCO}_{2}$ changes remain small and surface $\Omega_{\text {arag }}$ is approximately in equilibrium with atmospheric $\mathrm{CO}_{2}$ forcing (black lines in Fig. 11). In contrast, $\Omega_{\mathrm{arag}}$ and $\Delta \mathrm{pCO}_{2}$ in the Arctic surface (red lines in Fig. 11) show path-dependent relations to atmospheric $\mathrm{CO}_{2}$ : at identical $\mathrm{CO}_{2}$, the reduction in $\Omega_{\text {arag }}$ is (b) High: Arctic Ocean

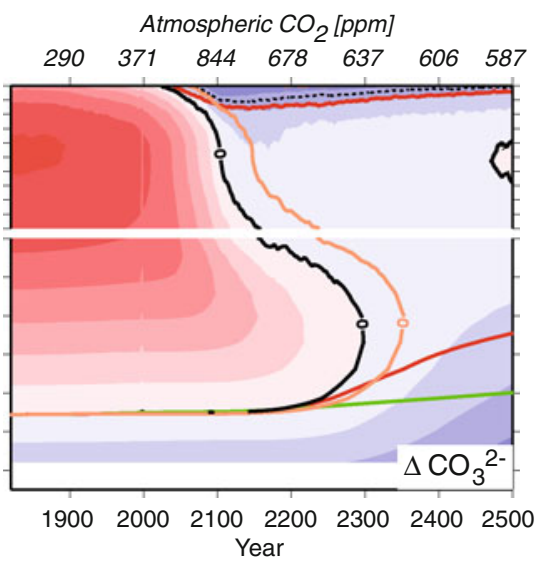

the aragonite saturation horizon $\left(\Omega_{\text {arag }}=100 \%\right)$ in the High (black), Low (red), Hist (green) and no-warming (orange) cases. Dashed lines denote the calcite saturation horizon $\left(\Omega_{\text {calc }}=100 \%\right)$ for the different cases. The evolution is plotted as function of time and of the annual mean atmospheric $\mathrm{CO}_{2}$ mixing ratio

0.13 units larger in year 2500 than in 2060 in the High case (arrow in Fig. 11a). $\Delta \mathrm{pCO}_{2}$, the driver for the air-sea carbon flux, remains above preindustrial during the 21 st century by up to $110 \mathrm{ppm}$ in the Arctic Ocean and approaches the preindustrial value only slowly after a few centuries. The delayed response in Arctic $\Omega_{\text {arag }}$ is a consequence of continued carbon uptake. This in turn is amplified by the large changes in the hydrological cycle. Annual mean sea ice volume is reduced by $65 \%$ by the end of the century in the High case. This results in a dilution of carbon and alkalinity in the surface, a propagation of the freshwater and tracer anomalies into the deeper layers, and an increase in the ice-free area available for air-sea gas exchange.

The anthropogenic $\mathrm{CO}_{2}$ perturbation penetrates into the deep ocean. As a consequence, the saturation horizon, i.e., 


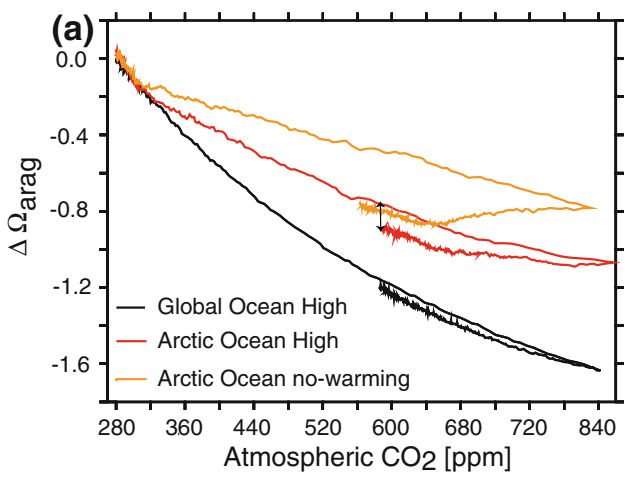

Fig. 11 Temporal evolution of changes in (a) surface saturation state with respect to aragonite $\left(\Omega_{\text {arag }}\right)$ and in (b) air-sea $\mathrm{CO}_{2}$ partial pressure difference $\left(\Delta \mathrm{pCO}_{2}\right)$ relative to the year 1820 as a function of atmospheric $\mathrm{CO}_{2}$ for different regions and scenarios. Note that the net

the surface separating over- and undersaturated water, shoals in most regions. In the High case, the anthropogenic perturbation leads to an abrupt shoaling of the global mean saturation horizon with respect to aragonite from about 1,720 to $320 \mathrm{~m}$ within few years around 2100 (Fig. 10), consistent with Orr et al. (2005). The saturation horizon is, on global average, projected to deepen by $90 \mathrm{~m}$ from 2100 to 2500. Significant shoaling of the saturation horizon is projected in the Atlantic Ocean due to the deep penetration of the anthropogenic perturbation. In the Arctic, undersaturation occurs also at the surface and expands towards depth (Fig. 10). At year 2300 in the High case, the Arctic Ocean is projected to become undersaturated with respect to aragonite throughout the water column.

A general decrease in ocean water saturation corresponds to a loss of volume providing habitat for many species that produce calcium carbonate structures. Following Steinacher et al. (2009a), we define five classes of saturation levels: (1) more than $400 \%$ saturated $\left(\Omega_{\text {arag }}>4\right)$, considered optimal for the growth of warm water corals, (2) 300-400\% saturated, considered as adequate for coral growth, (3) 200-300\% saturated and (4) 100-200\% saturated, both considered as marginal to inadequate for coral growth, though experimental evidence is scarce, and finally (5) undersaturated water considered to be unsuitable for pteropods. Figure $1 \mathrm{~h}$ shows the evolution of the ocean volume occupied by these classes for all simulations. In the High case, water masses with saturation above $300 \%$ vanish by $2070\left(\mathrm{CO}_{2} \approx 630 \mathrm{ppm}\right)$. Overall, the volume occupied by oversaturated water decreases from preindustrial 40 to $25 \%$ in 2100 and to $10 \%$ in 2300 , and the volume of undersaturated water increases accordingly. The Low case also features a large expansion of undersaturated water from 59 to $83 \%$ of ocean volume. In the Hist case, the perturbations in volume fractions are much more modest and trends are largely reversed in the well-saturated upper ocean over the next few centuries.

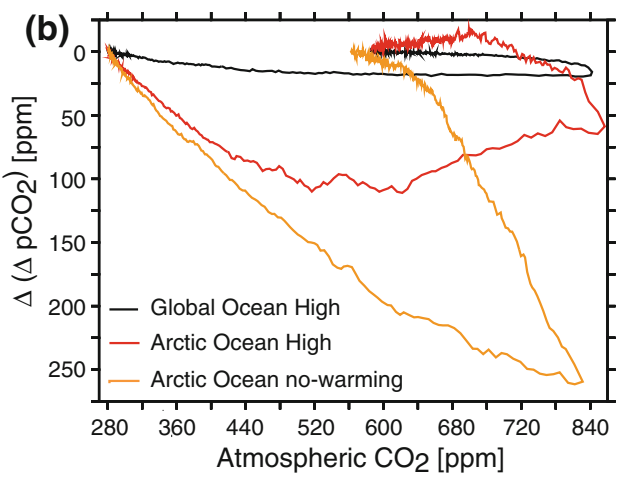

air-to-sea $\mathrm{CO}_{2}$ flux in the Arctic is lower in the no-warming than in the standard simulation as the ice-free area permitting gas exchange is increased in the latter

The response in the saturation state is delayed in the thermocline and the deep ocean reflecting the centennial timescales of the surface-to-deep transport of the anthropogenic carbon perturbation. In the High case, the volume of water with $\Omega_{\text {arag }}$ between 100 and $200 \%$ reaches its minimum around 200 years after emissions have been stopped. Accordingly, the volume of undersaturated water reaches its maximum around 2300. Afterwards, the volume fractions remain approximately stable; the fraction of supersaturated water expands by only $1 \%$ from 2300 to 2500 .

The probability for water to become undersaturated relative to calcite is reduced compared to aragonite, because the precipitation equilibrium is about $50 \%$ higher for calcite than for aragonite. In the High case, undersaturation of Arctic surface waters with respect to calcite is simulated to start later than for aragonite, but also persists for centuries (Fig. 9). In the Low case, surface waters remain supersaturated on annual and zonal average. The global mean calcite saturation horizon is located around $4,000 \mathrm{~m}$ and starts to shoal slowly in the 22nd century (Fig. 10).

The slow penetration of anthropogenic carbon into the deep ocean is also reflected in pH changes (Fig. 12). At the peak of the atmospheric $\mathrm{CO}_{2}$ concentration in 2100 in the High case, surface $\mathrm{pH}$ decreases by $0.3-0.4$ units relative to preindustrial in low and mid-latitudes and by up to 0.6 in northern high-latitudes and in the Arctic, while the $\mathrm{pH}$ changes are generally smaller at depth. However, by $2500 \mathrm{pH}$ decreases are larger at 2,000 $\mathrm{m}$ than at the time of peak atmospheric $\mathrm{CO}_{2}$ in year 2100 and with up to 0.3 units relatively large in the Southern Ocean and parts of the Atlantic.

Climate change influences $\mathrm{pH}$ levels at depth towards the end of the simulation, although with small magnitude $(<0.02)$. The contribution of alkalinity changes to the decrease in carbonate ions and $\mathrm{CaCO}_{3}$ saturation is generally small in year 2100; alkalinity changed little, except 
Fig. 12 Changes in $\mathrm{pH}$ for the period 2090-2099 (a, c) and for the period 2490-2499 $(\mathbf{b}, \mathbf{d})$ relative to the period 2000-2009 at the surface (a, b) and at a depth of $2,000 \mathrm{~m}$ (c, d) in the High case (a) Surface: 2090 - 2099

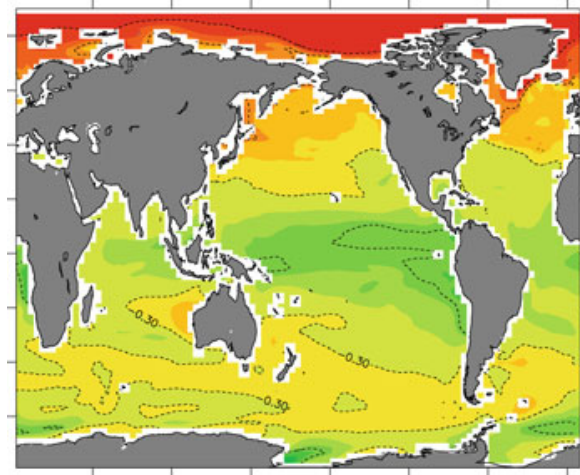

(c) 2000m: 2090 - 2099

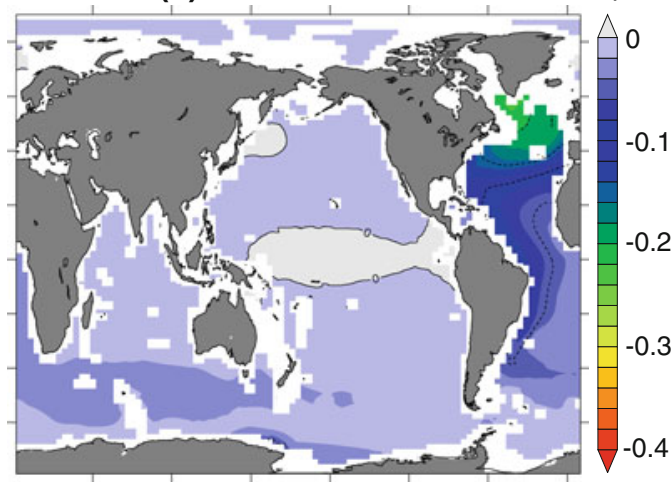

(b) Surface: 2490 - 2499
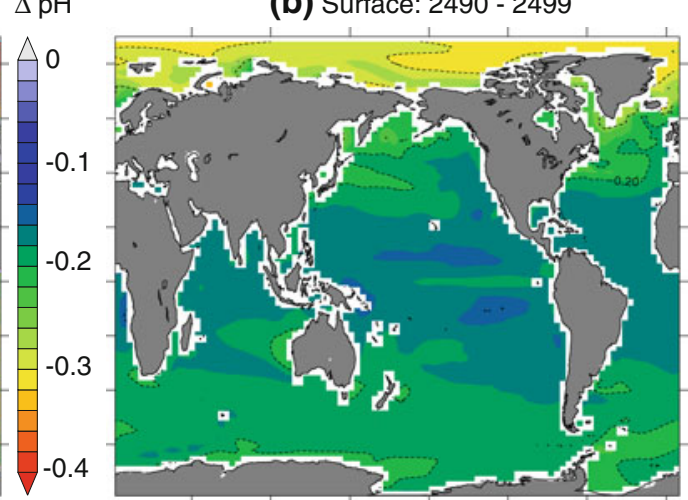

(d) 2000m: 2490 - 2499

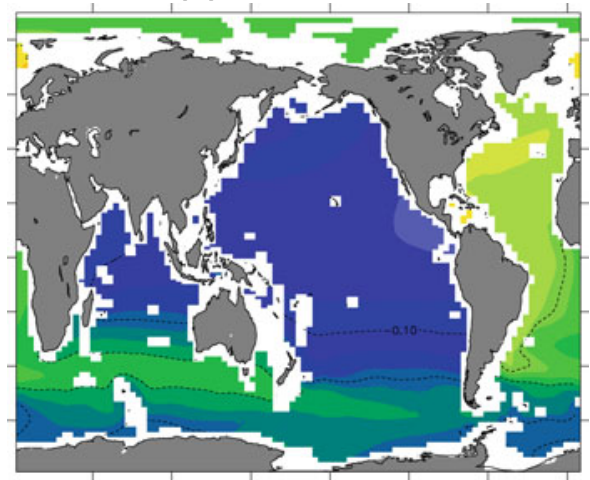

in the Arctic Ocean and in parts of the Atlantic Ocean. The simulated changes in deep ocean ventilation and production cause alkalinity to increase in the deep Atlantic and Pacific as already discussed in the context of the changes in the oceanic DIC contribution (Figs. 7b, 8b).

In conclusion, the modeled evolution of the aragonite saturation state and $\mathrm{pH}$ highlight that some impacts of $21 \mathrm{st}$ century fossil fuel carbon emissions are strongly delayed and maximum impacts are simulated centuries after emissions have been reduced, even for the extreme case of an immediate emission stop.

\section{Discussion and conclusion}

Three illustrative multi-gas emission commitment scenarios are analyzed with the CSM1.4-carbon model. Carbon and other anthropogenic emissions follow the historical trajectory, and a high (SRES A2) and low (SRES B1) emission scenario until 2100. Emissions are reduced to zero immediately in 2100 in the High and Low case and in 2000 in the Hist case.

The skill of the NCAR CSM1.4-carbon in representing climate and carbon and tracer distributions in the landocean-atmosphere system is documented in a number of papers (e.g. Doney et al. 2006; Frölicher et al. 2009;
Steinacher et al. 2009a, b). As usual, caveats apply. The complex spatio-temporal interactions of a wide range of processes and feedbacks need to be represented in a simplified way in any model system and the lack of understanding of some of the more intricate processes leads to additional uncertainties in climate projections. The NCAR CSM1.4-carbon features both a small climate sensitivity, the models response to a nominal increase in radiative forcing, as well as a small carbon cycle-climate feedback, the amplification of the atmospheric $\mathrm{CO}_{2}$ increase and global warming due to climate-biogeochemical coupling. The climate sensitivity is at the lower end of the observationally-constrained range (Meehl et al. 2007). The carbon cycle feedback amplifies 21 st century warming by a few percent only in contrast to more sensitive models (Schmittner et al. 2008; Friedlingstein et al. 2006). This implies that the projected changes are likely conservative estimates of the changes to come. In addition, several potential amplifying mechanisms are not considered. Melting of glaciers and ice sheets and a related slow-down of the ocean's overturning circulation and reduced uptake of heat and carbon are not considered. Uncertainties in projected precipitation changes are still relatively large in the current suite of AOGCMs (Meehl et al. 2007). NCAR CSM1.4 does not simulate the strong precipitation reduction in the Amazon basin that causes forest dieback and high 
atmospheric $\mathrm{CO}_{2}$ and large warming in the Hadley Centre model (Cox et al. 2000). Marine ecosystems and their role in the carbon cycle are parametrized in a highly simplified way in the NCAR CSM1.4-carbon in comparison to some more sophisticated representations (Bopp et al. 2001; Moore et al. 2002; Maier-Reimer et al. 2005; Manizza et al. 2008; Schmittner et al. 2008). Potential impacts of ocean acidification on the production and remineralization of organic matter and calcite and related climatic feedbacks are not taken into account; current experimental evidence on the expected future changes remain unclear. Reduced (enhanced) calcification and dissolution of $\mathrm{CaCO}_{3}$ would likely lead to a small negative (positive) effect on atmospheric $\mathrm{CO}_{2}$ (Gangst $\varnothing$ et al. 2008; Gehlen et al. 2007; Ridgwell et al. 2007). A potential weakening of the mineral-ballast affecting the organic matter flux to depth due to reduced shell weight could lead to a small positive effect on atmospheric $\mathrm{CO}_{2}$ (Heinze 2004), but could potentially expand hypoxic ocean regions (Hofmann and Schellnhuber 2009). A small negative effect on atmospheric $\mathrm{CO}_{2}$ has also been modeled by applying enhanced biotic carbon-tonitrogen drawdown under acidification as seen in mesocosm experiments (Oschlies et al. 2008). On land, biome distribution is prescribed in the model and changes in the distribution of plants are neglected. We expect from this an underestimation of carbon storage in today's temperature limited Arctic zone and in high altitude regions as tree are likely to expand polewards and upwards under warming (Joos et al. 2001). On the other hand, permafrost and peatlands (Tarnocai et al. 2009) are not explicitly treated and the potential release of methane and $\mathrm{CO}_{2}$ to the atmosphere is not considered (Lawrence and Slater 2005; Schuur et al. 2009). Overall, uncertainties in our climate projections increase with time, but also with the magnitude and duration of global warming, because not considered or unexpected feedbacks may come into play. On the other hand, results may be more reliable when future climate change remains modest. In other words, uncertainties are likely smaller for the Hist case than for the High and Low case. Despite the various caveats, the NCAR CSM1.4carbon has skill in representing some of the most fundamental processes in the climate-biogeochemical system and provides a useful framework to investigate potential future changes. Important with respect to the discussion of regional changes is that simulated interannual variability in precipitation and temperature in the NCAR CSM1.4 compares well with observation-based estimates.

A new finding of this study is that the perturbations in temperature and precipitation from historical emissions are largely reversible within centuries in most inhabited regions in the sense that the anthropogenic signal becomes smaller than regional natural unforced variability. The application of a dynamical coupled atmosphere-ocean general circulation model and our scenario setup allows us to discuss forced regional century-scale changes in comparison with internal climate variability in a dynamical self-consistent setting, thereby going beyond previous studies applying Earth System Models of Intermediate Complexity for long-term simulations (e.g. Plattner et al. 2008; Schmittner et al. 2008). EMICs typically use simplified atmosphere energy balance components and do not represent internal variability.

The finding of reversible regional temperature changes is not inconsistent with previous EMIC results of irreversible global temperature response to historical $\mathrm{CO}_{2}$ emissions only (Solomon et al. 2009; Matthews and Caldeira 2008). Atmospheric $\mathrm{CO}_{2}$ does not completely return to preindustrial values and associated radiative forcing, global mean surface temperature and sea level remain slightly elevated in the Hist simulations. Here, we analyzed regional changes instead of global mean indicators. Another difference to the earlier $\mathrm{CO}_{2}$-only scenarios is that the inclusion of non- $\mathrm{CO}_{2}$ GHGs causes a more rapid cooling after cessation of emissions due to their relatively short atmospheric perturbation lifetime. This demonstrates the potential benefits of non- $\mathrm{CO}_{2}$ greenhouse gas emission reductions.

The combination of a low climate sensitivity and a small carbon cycle-climate feedback in the CSM1.4-carbon leads to a smaller climate response to carbon emissions than in other comparable models (Friedlingstein et al. 2006). The CSM1.4 climate sensitivity of $2^{\circ} \mathrm{C}$ is at the lower bound of the range given by IPCC of $2^{\circ} \mathrm{C}$ to $4.5^{\circ} \mathrm{C}$ and lower than the best estimate of $3.2^{\circ} \mathrm{C}$ (Meehl et al. 2007). Thus, the question arises to which extent our result is robust. We have scaled the simulated temperature changes by a constant factor such as to match a climate sensitivity of 3.2 and $4.5^{\circ} \mathrm{C}$, respectively. Then, we compare again the increased anthropogenic signal with the (unchanged) variability from the control (Fig. 13). Globally, the area where the climate signal is smaller than regional internal variability is reduced from 75 to 54 and $43 \%$, respectively. Thus, even for a high climate sensitivity the regional perturbation becomes smaller than internal variability for almost half of the land and ocean area. Internal climate variability is only part of the natural climate variability that includes also variations in response to changes in solar irradiance and explosive volcanic eruptions (Gerber et al. 2003; Ammann et al. 2007). We conclude that the regional impact on temperature and annual-mean precipitation of historical greenhouse gas emissions becomes most probably smaller than natural (forced and unforced) variability over the next few centuries in most regions. The implication is that emission mitigation efforts have the potential to reverse current warming trends.

The irreversibility of 21 st century carbon emissions on human timescales (excluding technologies to remove 

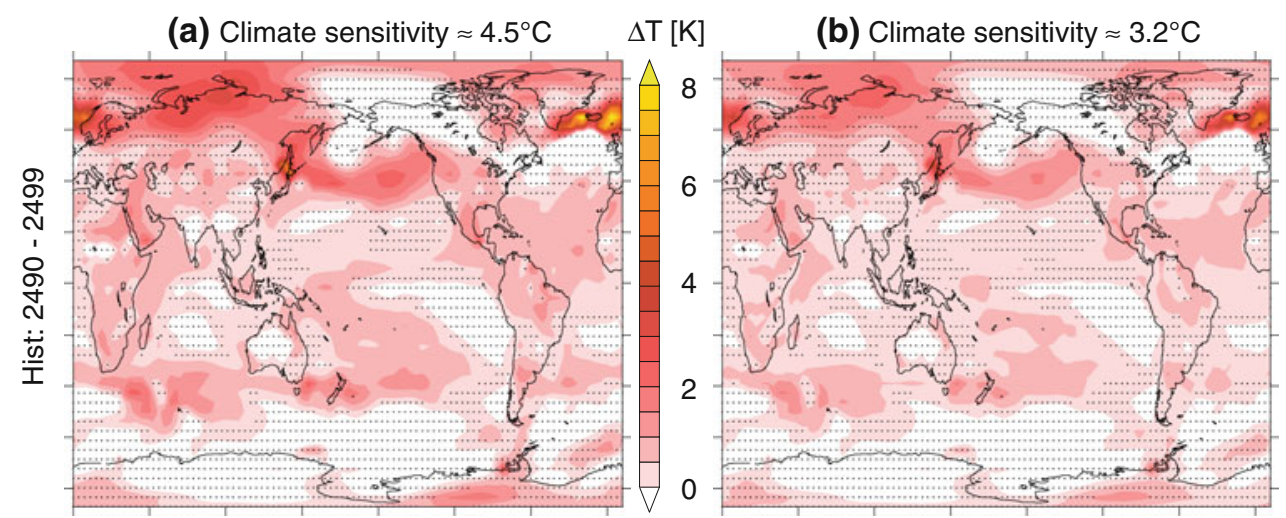

Fig. 13 Scaled decadal mean changes in surface temperature for the period 2490-2499 relative to preindustrial in the Hist case. Simulated changes are scaled with a factor of $(\mathbf{a}) 4.5^{\circ} \mathrm{C} / 2.0^{\circ} \mathrm{C}$ and $(\mathbf{b}) 3.2^{\circ} \mathrm{C} /$ $2.0^{\circ} \mathrm{C}$, thereby artificially increasing the model's climate sensitivity from 2.0 to $3.2^{\circ} \mathrm{C}$ and $4.5^{\circ} \mathrm{C}$. The latter represent the upper limit and

carbon from the atmosphere) is a robust result across the entire model hierarchy (Plattner et al. 2008; Siegenthaler and Oeschger 1978). The conclusions presented by Siegenthaler and Oeschger (1978) 30 years ago are confirmed with a comprehensive model: anthropogenic carbon emissions must be reduced in the coming decades if we want to avoid a dangerous perturbation of Earth's radiative balance. High 21 st century carbon emissions will impact climate and the geochemical state of the ocean for centuries to millennia. About $30 \%$ of anthropogenic carbon emissions remain airborne over centuries for cumulative emissions of a couple of 1,000 gigatons of carbon. In comparison to the pioneering box-model study by Siegenthaler and Oeschger (1978), we are now able to investigate the regional details of climate-carbon feedbacks and potential impacts in the dynamical setting of an Earth system model.

Competing processes and system time lags results in different evolution of the climate-land carbon feedbacks in different regions and in soil and vegetation. For example, soil carbon storage is initially reduced in the High case relative to the no-warming case as turnover rates increase with warming and moistening, but soil carbon storage becomes more important in the simulation with warming in the long term as more favorable growing conditions lead to higher carbon fluxes into vegetation and soils. In the tropics, regional differences in soil moisture regimes affect also regional carbon storage with some regions loosing carbon under dryer conditions, whereas other regions gain carbon when sufficient soil water is available to support fertilization by increasing $\mathrm{CO}_{2}$. Overall, the influence of opposing processes on carbon storage tend to partly cancel in the NCAR model and the climate-land carbon feedback remains small. The influence of climate change on ocean carbon uptake becomes more important with time and with the median in climate sensitivity of all AOGCMs used in the IPCC AR4 (Meehl et al. 2007). Stippling denotes the grid cells where the magnitude of change is smaller than the standard deviation from the (unscaled) control run

the slow penetration of anthropogenic carbon into the deep ocean.

Undersaturation in the Arctic becomes widespread for an atmospheric $\mathrm{CO}_{2}$ concentration reaching about $450 \mathrm{ppm}$ and saturation in the tropical ocean is strongly reduced, posing a threat for the survival of warm water corals. The precautionary principle, for instance mentioned by the United Nation Framework Convention on Climate Change (UNFCC), implies that atmospheric $\mathrm{CO}_{2}$ should be kept below $450 \mathrm{ppm}$ to avoid the risk of large-scale ecosystem changes.

Emerging trends in ocean acidification are projected to aggravate for high 21 st century emissions. The peak impact on ecosystems might become apparent only decades and centuries after carbon emissions have been reduced. An example is the continued large reduction in the volume of supersaturated water with respect to aragonite, providing habitat for calcifying organisms, after carbon emissions have been stopped. We find an increase in the volume of undersaturated water from 59 to 91 and $83 \%$ in the High and Low case, respectively. We show that the undersaturation of the entire Arctic Ocean persists a few centuries for business-as-usual (SRES A2) 21st century carbon emissions. Whereas the saturation state in mid-to-low latitudes surface waters closely follows atmospheric $\mathrm{CO}_{2}$, the saturation state in Arctic surface waters show path-dependent relation to atmospheric $\mathrm{CO}_{2}$. Our results complement the findings of Schmittner et al. (2008) who also highlight the delayed response of the climate system and the carbon cycle to a reduction in carbon emissions on a global scale.

Global Warming Potentials are used in the Kyoto protocol as a metric to compare and trade emissions of $\mathrm{CO}_{2}$ for emissions of other GHGs. Our discussion on non- $\mathrm{CO}_{2}$ forcing agents has been limited for the following reasons: (1) The anthropogenic perturbations in atmospheric 
$\mathrm{CH}_{4}, \mathrm{~N}_{2} \mathrm{O}$, tropospheric $\mathrm{O}_{3}, \mathrm{CFCs}$, or aerosol loads are largely reversible within a few weeks to a century. (2) The contribution of non- $\mathrm{CO}_{2}$ agents and other pollutants to ocean acidification is small. (3) Of the major anthropogenic GHG emissions, only the impact of 21 st century carbon emissions remains irreversible on century to millennium timescale. We argue that emissions of agents with a shortlived atmospheric perturbation lifetime should not be traded with emissions of long-lived GHGs, the latter posing a much more persistent climate and environmental change commitment. While the Kyoto basket approach to pool emissions of $\mathrm{CO}_{2}$ and other GHGs might have been useful to make first steps towards the goals of the UNFCC, it is now timely and necessary (Solomon et al. 2009) to distinguish between short-lived agents such as $\mathrm{CH}_{4}, \mathrm{~N}_{2} \mathrm{O}$, hydro- and perfluorocarbons and agents with a perturbation lifetime of millennia such as $\mathrm{CO}_{2}$ or $\mathrm{SF}_{6}$ and other fully fluorinated species.

Our study shows that the influence of 20th century emissions of $\mathrm{CO}_{2}$ and other agents on regional temperature and precipitation is largely reversible; forced regional changes become smaller than innterannual variability. In contrast, continued carbon emissions over the 21 st century causes irreversible climate change on both the global and regional scale. Impacts related to ocean acidification and sea level rise continue to aggravate for centuries even for the hypothetical case of an immediate emission stop.

Acknowledgments Simulations were carried out at the Swiss National Computing Center in Manno, Switzerland. This study is supported by the EU projects CARBOOCEAN (511176), EUROCEANS (511106-2) and EPOCA (FP7/2007-2013; no. 211384), and the Swiss National Science Foundation. We thank S. C. Doney, I. Fung, K. Lindsay, J. John and colleagues for providing the CSM1.4carbon code. We thank G.-K. Plattner, K. Strassmann, C. C. Raible and $\mathrm{H}$. Fischer for providing the forcing dataset and discussion, and $\mathrm{J}$. Orr and M. Steinacher for the standard OCMIP carbonate chemistry routines.

\section{References}

Ammann CM, Joos F, Schimel DS, Otto-Bliesner BL, Tomas RA (2007) Solar influence on climate during the past millennium: results from transient simulations with the NCAR climate system model. Proc Natl Acad Sci 104(10):3713-3718. doi:10.1073/ pnas.0605064

Archer D, Brovkin V (2008) The millennial atmospheric lifetime of anthropogenic $\mathrm{CO}_{2}$. Clim Change 90:283-297. doi:10.1007/ s10584-008-9413-1

Archer D, Kheshgi H, Maier-Reimer E (1998) Dynamic of fossil fuel $\mathrm{CO}_{2}$ neutralization by marine $\mathrm{CaCO}_{3}$. Glob Biogeochem Cycles 12(2):259-276. doi:10.1029/98GB00744

Archer D, Eby M, Brovkin V, Ridgwell A, Cao L, Mikolajewicz U, Caldeira K, Matsumoto K, Munhoven G, Montenegro A, Tokos K (2009) Atmospheric lifetime of fossil fuel carbon dioxide. Annu Rev Earth Planet Sci 373:21.1-21.18. doi:10.1146/ annurev.earth.031208.100206
Blackford JC, Gilbert FJ (2007) $\mathrm{pH}$ variability and $\mathrm{CO}_{2}$ induced acidification in the North Sea. J Mar Syst 64:229-241. doi: 10.1016/j.jmarsys.2006.03.016

Bopp L, Monfray P, Aumont O, Dufresne JL, Treut HL, Madec G, Terray L, Orr J (2001) Potential impact of climate change on marine export production. Glob Biogeochem Cycles 15:81-99. doi:10.1029/1999GB001256

Brohan P, Kennedy JJ, Harris I, Tett SFB, Jones PD (2006) Uncertainty estimates in regional and global observed temperature changes: a new dataset from 1850. J Geophys Res 111:D12-D106. doi:10.1029/2005JD006548

Caldeira K, Wickett ME (2005) Ocean model predictions of chemistry changes from carbon dioxide emissions to the atmosphere and ocean. J Geophys Res 110:C09S04. doi:10.1029/ 2004JC002671

Cao L, Caldeira K, Jain AK (2007) Effects of carbon dioxide and climate change on ocean acidification and carbonate mineral saturation. Geophys Res Lett 34:L05607. doi:10.1029/ 2006GL028605

Conkright ME, Locarnini RA, Garcia H, Brien TO, Boyer T, Stephens C, Antonov J (2002) World Ocean Atlas 2001: objective analyses, data statistics, and figures, cd-rom documentation. Technical report National Oceanographic Data Center, Silver Spring, MD

Cox PM, Betts RA, Jones CD, Spall SA, Totterdell IJ (2000) Acceleration of global warming due to carbon-cycle feedbacks in a coupled climate model. Nature 408(6809):184-187. doi: $10.1038 / 35041539$

De'ath G, Lough JM, Fabricius KE (2009) Declining coral calcification on the great barrier reef. Science 323(5910):116-119. doi: $10.1126 /$ science. 1165283

Doney SC, Lindsay K, Fung I, John J (2006) Natural variability in a stable, 1000-year global coupled climate-carbon cycle simulation. J Clim 19:3033-3054. doi:10.1175/JCLI3783.1

Doney SC, Fabry VJ, Feely RA, Kleypas JA (2009) Ocean acidification: the other $\mathrm{CO}_{2}$ problem. Annu Rev Mar Sci 1:169-192. doi:10.1146/annurev.marine.010908.163834

Eby M, Zickfeld K, Montenegro A, Archer D, Meissner KJ, Weaver AJ (2009) Lifetime of anthropogenic climate change: Millennial time-scales of potential $\mathrm{CO}_{2}$ and surface temperature perturbations. J Clim 22:2501- 2511. doi:10.1175/2008/JCLI2554.1

Fabry VJ, Seibel BA, Feely RA, Orr JC (2008) Impacts of ocean acidification on marine fauna and ecosystem processes. ICES $\mathrm{J}$ Mar Sci 65:414-432. doi:10.1093/icesjms/fsn048

Feely RA, Sabine CL, Lee K, Berelson W, Kleypas J, Fabry VJ, Millero FJ (2004) Impact of anthropogenic $\mathrm{CO}_{2}$ on the $\mathrm{CaCO}_{3}$ system in the oceans. Science 305(5682):362-366. doi:10.1126/ science. 1097329

Forster P, Ramaswamy V, Artaxo P, Berntsen T, Betts R, Fahey DW, Haywood J, Lean J, Lowe DC, Myhre G, Nganga J, Prinn R, Raga G, Schulz M, Dorland RV (2007) Changes in atmospheric constituents and in radiative forcing. In: Solomon S, Qin D, Manning M, Chen Z, Marquis M, Averyt K, Tignor M, Miller H (eds) Climate change 2007: the physical science basis: contribution of Working Group I to the fourth assessment report of the Intergovernmental Panel on Climate Change, Cambridge University Press, Cambridge, United Kingdom and New York, NY, USA, pp 129-234

Friedlingstein P, Cox P, Betts R, Bopp L, von Bloh W, Brovkin V, Cadule P, Doney S, Eby M, Fung I, Bala G, John J, Jones C, Joos F, Kato T, Kawamiya M, Knorr W, Lindsay K, Matthews HD, Raddatz T, Rayner P, Reick C, Roeckner E, Schnitzler KG, Schnur R, Strassmann K, Weaver AJ, Yoshikawa C, Zeng N (2006) Climate-carbon cycle feedback analysis: results from the C4MIP model intercomparison. J Clim 19(14):3337-3353. doi: 10.1175/JCLI3800.1 
Frölicher TL, Joos F, Plattner GK, Steinacher M, Doney SC (2009) Natural variability and anthropogenic trends in oceanic oxygen in a coupled carbon cycle-climate model ensemble. Glob Biogeochem Cycles 23:GB1003. doi:10.1029/2008GB003316

Fung IY, Doney SC, Lindsay K, John J (2005) Evolution of carbon sinks in a changing climate. Proc Natl Acad Sci 102(32):1120111206. doi:10.1073/pnas.0504949102

Gangst $\varnothing$ R, Gehlen M, Schneider B, Bopp L, Aumont O, Joos F (2008) Modeling the marine aragonite cycle: changes under rising carbon dioxide and its role in shallow water $\mathrm{CaCO}_{3}$ dissolution. Biogeosciences 5:1057 - 1072

Gehlen M, Gangst $\varnothing$ R, Schneider B, Bopp L, Aumont O, Ethe C (2007) The fate of pelagic $\mathrm{CaCO}_{3}$ production in a high $\mathrm{CO}_{2}$ ocean: a model study. Biogeosciences 4:505- 519

Gerber M, Joos F, Vazquez-Rodriguez M, Touratier F, Goyet C (2009) Regional air-sea fluxes of anthropogenic carbon inferred with an Ensemble Kalman Filter. Glob Biogeochem Cycles 23:GB1013. doi:10.1029/2008GB003247

Gerber S, Joos F, Brügger PP, Stocker TF, Mann ME, Sitch S, Scholze M (2003) Constraining temperature variations over the last millennium by comparing simulated and observed atmospheric $\mathrm{CO}_{2}$. Clim Dyn 20:281-299. doi:10.1007/s00382-0020270-8

Gruber N, Gloor M, Fletcher SEM, Doney SC, Dutkiewicz S, Follows M, Gerber M, Jacobson AR, Joos F, Lindsay K, Menemenlis D, Mouchet A, Müller SA, Sarmiento JL, Takahashi T (2009) Oceanic sources, sinks and transport of atmospheric $\mathrm{CO}_{2}$. Glob Biogeochem Cycles 23:GB1005. doi:10.1.1029/2008GB003349

Heinze $\mathrm{C}$ (2004) Simulating oceanic $\mathrm{CaCO}_{3}$ export production in the greenhouse. Geophys Res Lett 31:L16308. doi:10.1029/ 2004GL020613

Hoegh-Guldberg O, Mumby PJ, Hooten AJ, Steneck RS, Greenfield P, Gomez E, Harvell CD, Sale PF, Edwards AJ, Caldeira K, Knowlton N, Eakin CM, Iglesias-Prieto R, Muthiga N, Bradbury RH, Dubi A, Hatziolos ME (2007) Coral reefs under rapid climate change and ocean acidification. Sience 318:1737-1742. doi:10.1126/science.115,209

Hofmann M, Schellnhuber HJ (2009) Ocean acidification affects marine carbon pump and triggers extended marine oxygen holes. Proc Natl Acad Sci 106(9):3017-3022. doi:10.1073/pnas. 0813384106

Iglesias-Rodriguez MD, Halloran PR, Rickaby REM, Hall IR, Colmenero-Hidalgo E, Gittins JR, Green DRH, Tyrell T, Gibbs SJ, von Dassow P, Rehm E, Armbrust EV, Boessenkool KP (2008) Phytoplankton calcification in a high- $\mathrm{CO}_{2}$ world. Science 320(5874):336-340. doi:10.1126/science.1154122

Joos F, Spahni R (2008) Rates of change in natural and anthropogenic radiative forcing over the past 20,000 years. Proc Natl Acad Sci 105(5):1425-1430. doi:10.1073/pnas.0707386105

Joos F, Plattner GK, Stocker TF, Marchal O, Schmittner A (1999) Global warming and marine carbon cycle feedbacks on future atmospheric $\mathrm{CO}_{2}$. Science 284(5413):464-467. doi:10.1126/ science.284.5413.464

Joos F, Prentice IC, Sitch S, Meyer R, Hooss G, Plattner GK, Gerber S, Hasselmann K (2001) Global warming feedbacks on terrestrial carbon uptake under the Intergovernmental Panel on Climate Change IPCC emission scenarios. Glob Biogeochem Cycles 15(4):891-907

Key RM, Kozyr A, Sabine CL, Lee K, Wanninkhof R, Bullister J, Feely RA, Millero F, Mordy C, Peng TH (2004) A global ocean carbon climatology: results from GLODAP. Glob Biogeochem Cycles 18:GB4031. doi:10.1029/2004GB002247

Kleypas JA, Buddemeier RW, Archer D, Gattuso JP, Langdon C, Opdyke BN (1999) Geochemical consequences of increased atmospheric carbon dioxide on coral reefs. Science 284(5411): 118-120. doi:10.1126/science.284.5411.118
Langdon C, Atkinson MJ (2005) Effect of elevated $\mathrm{pCO}_{2}$ on photosynthesis and calcification of corals and interactions with seasonal change in temperature/irradiance and nutrient enrichment. J Geophys Res 110(C09S07) doi:10.1029/2004JC002576

Lawrence DM, Slater AG (2005) A projection of severe near-surface permafrost degradation during the 21 st century. Geophys Res Lett 32:L24401. doi:10.1029/2005GL025080

Lenton TM, Williamson MS, Edwards NR, Marsh R, Price AR, Ridgwell AJ, Shepherd JG, Cox SJ, Team TG (2006) Millennial timescale carbon cycle and climate change in an efficient Earth system model. Clim Dyn 26:687-711. doi:10.1007/s00382-0060109-9

Lüthi D, Floch ML, Bereiter B, Blunier T, Barnola JM, Siegenthaler U, Raynaud D, Jouzel J, Fischer H, Kawamura K, Stocker TF (2008) High-resolution carbon dioxide concentration record 650,000-800,000 years before present. Science 453:379-382. doi:10.1038/nature06949

Maier-Reimer E, Kriest I, Segschneider J, Wetzel P (2005) The HAMburg Ocean Carbon Cycle model HAMOCC5.1. Berichte zur Erdsystemforschung 14/2005, Max Planck-Institut für Meteorologie, Hamburg, Germany

Manizza M, Quéré CL, Watson AJ, Buitenhuis ET (2008) Ocean biogeochemical response to phytoplankton-light feedback in a global model. J Geophys Res 113:C10010. doi:10.1029/ 2007JC004478

Matthews HD, Caldeira K (2008) Stabilizing climate requires nearzero emissions. Geophys Res Lett 35:L04705. doi:10.1029/2007 GL032388

Meehl GA, Washington WM, Collins WD, Arblaster JM, Hu A, Buja LE, Teng WGSH (2005) How much more global warming and sea level rise? Science 307(5716):1769-1772. doi:10.1126/science. 1106663

Meehl GA, Stocker TF, Collins WD, Friedlingstein P, Gaye AT, Gregory JM, Kitoh A, Knutti R, Murphy JM, Noda A, Raper SCB, Watterson IG, Weaver AJ, Zhao ZC (2007) Global Climate Projections. In: Solomon S, Qin D, Manning M, Chen Z, Marquis M, Averyt KB, Tignor M, Miller HL (eds) Climate Change 2007: the physical science basis. Contribution of Working Group I to the Fourth Assessment Report of the Intergovernmental Panel on Climate Change, Cambridge University Press, Cambridge, pp 747-845

Mikolajewicz U, Gröger M, Maier-Reimer E, Schurgers G, Vizcaino M, Winguth AME (2007) Long-term effects of anthropogenic $\mathrm{CO}_{2}$ emissions simulated with a complex Earth system model. Clim Dyn 28(6):599-633. doi:10.1007/s00382-006-0204-y

Mitchell TD, Jones PD (2005) An improved method of constructing a database of monthly climate observations and associated highresolution grids. Int J Climatol 25(6):693-712. doi:10.1002/joc. 1181

Montenegro A, Brovkin V, Eby M, Archer D, Weaver AJ (2007) Long term fate of anthropogenic carbon. Geophys Res Lett 34:L19707. doi:10.1029/2007GL030905

Moore JK, Doney SC, Kleypas JA, Glover DM, Fung IY (2002) An intermediate complexity marine ecosystem model for the global domain. Deep Sea Res II 49:403-462

Müller SA, Joos F, Edwards NR, Stocker TF (2006) Water mass distribution and ventilation time scales in a cost-efficient, threedimensional ocean model. J Clim 19(21):5479-5499. doi: 10.1175/JCLI3911.1

Najjar RG, Jin X, Louanchi F, Aumont O, Caldeira K, Doney SC, Dutay JC, Follows M, Gruber N, Joos F, Lindsay K, MaierReimer E, Matear RJ, Matsumoto K, Monfray P, Mouchet A, Orr JC, Plattner GK, Sarmiento JL, Schlitzer R, Slater RD, Weirig MF, Yamanaka Y, Yool A (2007) Impact of circulation on export production, dissolved organic matter, and dissolved oxygen in the ocean: results from phase II of the Ocean 
Carbon-Cycle Model Intercomparison Project (OCMIP-2). Glob Biogeochem Cycles 21:GB3007. doi:10.1029/2006GB002857

Orr JC, Fabry VJ, Aumont O, Bopp L, Doney SC, Feely RM, Gnanadesikan A, Gruber N, Ishida A, Joos F, Key RM, Lindsay K, Maier-Reimer E, Matear RJ, Monfray P, Mouchet A, Najjar RG, Plattner GK, Rodgers KB, Sabine CL, Sarmiento JL, Schlitzer R, Slater RD, Totterdell IJ, Weirig MF, Yamanaka Y, Yool A (2005) Anthropogenic ocean acidification over the twenty-first century and its impact on marine calcifying organisms. Nature 437:681-686. doi:10.1038/nature04095

Oschlies A, Schulz KG, Riebesell U, Schmittner A (2008) Simulated 21 st century's increase in oceanic suboxia by $\mathrm{CO}_{2}$-enhanced biotic carbon export. Glob Biogeochem Cycles 22(4):GB4008. doi:10.1029/2007GB003147

Plattner GK, Joos F, Stocker TF, Marchal O (2001) Feedback mechanisms and sensitivities of ocean carbon uptake under global warming. Tellus B 53(5):564-592. doi:10.1034/j.1600-0889

Plattner GK, Knutti R, Joos F, Stocker TF, von Bloh W, Brovkin V, Cameron D, Driesschaert E, Dutkiewiz S, Eby M, Edwards NR, Fichefet T, Hargreaves JC, Jones CD, Loutre MF, Matthews HD, Mouchet A, Müller SA, Nawrath S, Price A, Sokolov A, Strassmann KM, Weaver AJ (2008) Long-term climate commitments projected with climate-carbon cycle models. J Clim 21(12):2721-2751. doi:10.1175/2007JCLI1905.1

Randerson JT, Thompson MV, Conway TJ, Fung IY, Field CB (1997) The contribution of terrestrial sources and sinks to trends in the seasonal cycle of atmospheric carbon dioxide. Glob Biogeochem Cycles 11:535-560

Ridgwell A, Zondervan I, Hargreaves JC, Bijma J, Lenton TM (2007) Assessing the potential long-term increase of oceanic fossil fuel $\mathrm{CO}_{2}$ uptake due to $\mathrm{CO}_{2}$-calcification feedback. Biogeosciences 4:481-492

Sabine CL, Feely RA, Gruber N, Key RM, Lee K, Bullister JL, Wanninkhof R, Wong CS, Wallace DWR, Tilbrook B, Millero FJ, Peng TH, Koyzr A, Ono T, Rios AF (2004) The oceanic sink for anthropogenic $\mathrm{CO}_{2}$. Science 305:367-371. doi:10.1126/ science. 1097403

Schmittner A, Oschlies A, Matthews HD, Galbraith ED (2008) Future changes in climate, ocean circulation, ecosystems, and biogeochemical cycling simulated for a business-as-usual $\mathrm{CO}_{2}$ emission scenario until year 4000 AD. Global Biogeochem Cycles 22:GB1013, 10.1029/2007GB002953
Schuur EAG, Vogel JG, Crummer KG, Lee H, Sickman JO, Osterkamp TE (2009) The effect of permafrost thaw on old carbon release and net carbon exchange from tundra. Nature 459:556-559. doi:10.1038/nature08031

Siegenthaler U, Joos F (1992) Use of a simple model for studying oceanic tracer distributions and the global carbon cycle. Tellus B 44:186-207

Siegenthaler U, Oeschger H (1978) Predicting future atmospheric carbon dioxide levels. Science 199(4327):388-395. doi: 10.1126/science.199.4327.388

Solomon S, Plattner GK, Knutti R, Friedlingstein P (2009) Irreversible climate change due to carbon dioxide emissions. Proc Natl Acad Sci 106(6):1704-1709. doi:10.1073/pnas.0812721106

Steinacher M, Joos F, Frölicher TL, Plattner GK, Doney SC (2009a) Imminent ocean acidification in the Arctic projected with the NCAR global coupled carbon cycle-climate model. Biogeosciences 6:515-533

Steinacher M, Joos F, Frölicher TL, Bopp L, Cadule P, Doney SC, Gehlen M, Schneider B, Segschneider J (2009b) Projected 21st century decrease in marine productivity: a multi-model analysis. Biogeosci Discuss 6:7933-7981

Strassmann KM, Joos F, Fischer G (2008) Simulating effects of land use changes on carbon fluxes: past contributions to atmospheric $\mathrm{CO}_{2}$ increases and future commitments due to losses of terrestrial sink capacity. Tellus B 60(4):583-603. doi:10.1111/j.16000889.2008.00340.x

Strassmann KM, Joos F, Plattner GK (2009) $\mathrm{CO}_{2}$ and non- $\mathrm{CO}_{2}$ radiative forcing in climate projections for twenty-first century mitigation. Clim Dyn 33(6):737-749. doi:10.1007/s00382-0080505-4

Tarnocai C, Canadell JG, Schuur EAG, Kuhry P, Mazhitova G, Zimov S (2009) Soil organic carbon pools in the northern circumpolar permafrost region. Global Biogeochem Cycles 23:GB2023. doi:10.1029/2008GB003327

Van Vuuren DP, Meinshausen M, Plattner GK, Joos F, Strassmann KM, Smith SJ, Wigley TML, Raper SCB, Riahi K, de la Chesnaye F, den Elzen M, Fujino J, Jiang K, Nakicenovic N, Paltsev S, Reilly JM (2008) Temperature increase of 21st century stabilization scenarios. Proc Natl Acad Sci 105(40): 15258-15262. doi:10.1073pnas.0711129105 